\title{
Unjustifiable Expectations: Laying to Rest the Ghosts of Allotment-Era Settlers
}

\author{
Ann E. Tweedy*
}

"[T] he feeling [among non-Indians in the vicinity of the Cheyenne River Sioux Reservation] is that the Indian is fair game for anyone who can hit the mark ...."

-Superintendent Thomas J. King, March 25, $1912^{1}$

\section{INTRODUCTION}

During the allotment era, the federal government took land from tribes and parceled some of it out to individual tribal members, while, in most cases, selling off the remainder to non-Indian settlers. Those actions, which are properly understood as unconstitutional takings, have been reinforced through decades of Supreme Court precedent. Specifically, the Court has used the now repudiated federal allotment policy, which contemplated eventual abolition of tribal governments, to justify contemporary incursions on tribal jurisdictional authority as well as other limitations

\footnotetext{
* Assistant Professor, Hamline University School of Law. I would like to thank Richard Delgado, Al Brophy, Bethany Berger, Marc Poirier, Steve Macias, Kevin Maillard, Shelley Cavalieri, John Noyes, Urs Laeuchli, Marie Failinger and the faculty at Hamline University School of Law for commenting on drafts and presentations of this Article, as well as the participants at LatCrit XVI, Michigan State University's Eighth Annual Indigenous Law Conference, the Fifteenth Annual Conference of the Association for the Study of Law, Culture and the Humanities, and the Forty-fourth Annual Dakota Conference. Thank you also to Stef Hedlund, Brice Zabel, and Benjamin Ranallo for their invaluable research assistance, to the editors at the Seattle University Law Review, and to the librarians and library staff at Michigan State University College of Law, Hamline University School of Law, Newberry Library, the Native American Rights Fund's National Indian Law Library, and the South Dakota State Archives, particularly Brent Domann, Megan Koltes, David Selden, and Matthew Reitzel. Finally, I am grateful to Hamline University School of Law for a research grant that helped make this Article possible.

1. Frederick E. Hoxie, JuRisdiction of THE CHEYENNE RIVER Sioux INDIAN RESERVATION: AN ANALysis OF THE CAUSES AND CONSEQUENCES OF THE ACT OF MAY 29, 1908, app. 81, at 5 (prepared for United States v. A Juvenile, 453 F. Supp. 1171 (D.S.D. 1978), vacated, Dupris v. United States, 446 U.S. 980 (1980)) (on file with author).
} 
on tribal sovereign rights. In this way, the Court builds new injustices upon old ones.

This Article responds to this Supreme Court precedent with two main points. First, it shows that non-Indians at the time had notice that the allotment policy was unfair to tribes (and that they sometimes directly advocated for its injustices). From this information, I argue that non-Indian purchasers of tribal lands - and subsequent purchasers from them-should not be understood to have had justifiable expectations that the reservations would disappear and that they therefore could not be subject to tribal jurisdiction in the future. Second, I argue that the Supreme Court should stop using the troubled history of allotment, which it construes based on incomplete information and without taking account of tribal interests and perspectives, to justify further restrictions on tribal sovereignty. In the late $1800 \mathrm{~s}$, the federal government embarked on a program of taking communally held tribal lands and redistributing some of the taken lands to individual Indians to force Indians to espouse a white understanding of property rights. Remaining "surplus" reservation lands were usually sold off to whites. ${ }^{2}$ This allotment of tribal lands was part of a broader scheme to assimilate Indians, the overarching goal of which was to "kill the Indian . . . and save the man." Allotment was halted in 1934, but not before tribes had lost a total of 90 million of the 138 million acres they had held at the beginning of the allotment period. ${ }^{4}$ The allotment process left affected reservations in complicated, checkerboard patterns of Indian and non-Indian ownership, which continue to interfere with effective governance of such reservations and to cause considerable jurisdictional confusion today. These difficulties are due, in large part, to the Supreme Court's reluctance to hold that tribes have jurisdiction over nonmembers, despite federal law to the contrary. ${ }^{5}$ Moreover, as discussed

2. General Allotment Act, ch. 119, § 5, 24 Stat. 388 (1886); Frederick E. HoxIE, A FINAL Promise: The Campaign to Assimilate Indians, 1880-1920, 156 (1984); Judith V. Royster, The Legacy of Allotment, 27 ARIZ. ST. L.J. 1, 13 (1995).

3. See Addie C. Rolnick, The Promise of Mancari: Indian Political Rights as Racial Remedy, 86 N.Y.U. L. REV. 958, 980 (2011).

4. See, e.g., COHEN's HANDBOOK OF FEDERAL INDIAN LAW $§ 1.04$ (Nell Jessup Newton et al. eds., 2005) [hereinafter COHEN's HANDBOOK].

5. See, e.g., Ann E. Tweedy, Connecting the Dots Between the Constitution, the Marshall Trilogy, and United States v. Lara: Notes Toward A Blueprint for the Next Legislative Restoration of Tribal Sovereignty, 42 U. MiCH. J.L. REFORM 651, 674-75, 684-87, 694-95 (2009) (describing the governance problems and jurisdictional confusion on reservations that result from the Court's divestment of tribal sovereignty); see also Matthew L.M. Fletcher, Commentary: In Pursuit of Tribal Economic Development as a Substitute for Reservation Tax Revenue, 80 N.D. L. REV. 809, 822-23 (2004) (discussing the Indian Country Statute, 18 U.S.C. § 1151); Gloria Valencia-Weber, The Supreme Court's Indian Law Decisions: Deviations from Constitutional Principles and the Crafting of 
below, the Supreme Court frequently invokes, both explicitly and implicitly, the justifiable expectations of non-Indian allotment-era purchasers regarding the disappearance of reservations to support its holdings denying tribal jurisdiction. ${ }^{6}$

While the Supreme Court routinely relies on the "justifiable expectations" of non-Indian purchasers to support rulings that are adverse to tribes, ${ }^{7}$ the Court never uses historical sources to unearth the true substance of these expectations, nor does it explain why they were justifiable. These presumed expectations thus form a significant part of the Supreme Court's justification for impeding tribes from effectively governing their own reservations, and the Court's use of these expectations helps to maintain an atmosphere of lawlessness on reservations. ${ }^{8}$

My purpose in this Article is to question both the substance of these presumed expectations and their justifiability. I begin this questioning with a thorough analysis of previously unexamined historical newspaper articles concerning non-Indian settlement of Indian reservations during the allotment era. I then argue that, as reflected by the above quote from Superintendent King, most non-Indians during the allotment period cared little about whether Indians were treated justly. Furthermore, I argue that many non-Indians had notice that tribes were being unjustly deprived of their lands through the allotment process, and that some non-Indians even advocated for this very injustice to occur. Both notice of injustice and complicity in the government's unjust actions precluded non-Indian purchasers from forming justifiable expectations. This rigorous, context-specific look at non-Indian expectations suggests that, in sharp contrast to current Supreme Court practice, tribal jurisdiction over nonmembers should generally be upheld and Indian reservations should not generally be held to have been diminished or disestablished as a result of allotment.

In examining the history of allotment, I focus on one of the largest tribes, the Sioux Nation, which lost over 30 million acres in two early cessions to the federal government ${ }^{9}$ and which continued to lose lands

Judicial Smallpox Blankets, 5 U. PA. J. CONST. L. 405, 473 (2003) (same). See generally Royster, supra note 2.

6. See, e.g., Philip P. Frickey, A Common Law for Our Age of Colonialism: The Judicial Divestiture of Indian Tribal Authority Over Nonmembers, 109 YALE L.J. 1, 57 (1999).

7. See, e.g., Plains Commerce Bank v. Long Family Land \& Cattle Co., 554 U.S. 316, 337 (2008); Rosebud Sioux Tribe v. Kneip, 430 U.S. 584, 602-05 (1977); Frickey, supra note 6, at 21-27, $38,45,48,57$.

8. See, e.g., Tweedy, supra note 5, at 684-87, 689-95.

9. Alexandra New Holy, The Heart of Everything That Is: Paha Sapa, Treaties, and Lakota Identity, 23 OKLA. City U. L. REV. 317, 328 (1998) (detailing a loss of 22.8 million acres in 1877); 
throughout the allotment period. I particularly concentrate on one of its constituent tribes, the Cheyenne River Sioux Tribe. As is its practice generally when deciding tribal jurisdiction and reservation diminishment cases, the Supreme Court has repeatedly analyzed and relied upon land cessions by constituent tribes of the Sioux Nation in determining whether individual Sioux reservations have been diminished and whether these tribes have jurisdiction over non-Indians on their reservations. And the Cheyenne River Sioux Tribe has been involved in more than its share of such cases. ${ }^{10}$ Moreover, the three poorest counties in the United States today are home to Sioux reservations in South Dakota, and one of them comprises part of the Cheyenne Sioux Reservation. ${ }^{11}$ Crime on several of these reservations is literally epidemic. ${ }^{12}$ Both the widespread poverty on these reservations and their lawless character can be linked to the now repudiated allotment policy. ${ }^{13}$

Part II of this Article explains the substance of the General Allotment $\mathrm{Act}^{14}$ (GAA) and the means by which the federal government implemented both the GAA and the broader federal allotment policy. Part III describes the Supreme Court's current use of the repudiated allotment policy, including reliance on non-Indian expectations, in deciding cases on tribal jurisdiction and reservation boundaries. Based largely on my own original historical research, Part IV first delineates the substance of non-Indian expectations during the allotment era-especially with regard to purchases of Sioux lands - and then assesses the justifiability of these

Herbert T. Hoover, The Sioux Agreement of 1889 and its Aftermath, 19 S.D. HIST. 56, 68 (1989) (describing loss of over nine million acres in 1889).

10. See, e.g., Plains Commerce Bank, 554 U.S. at 316 (addressing the Cheyenne River Sioux Tribe's civil jurisdiction over a non-Indian business); South Dakota v. Bourland, 508 U.S. 679 (1993) (addressing Cheyenne River Sioux Tribe's civil regulatory jurisdiction over a portion of tribal lands that the federal government had taken for a dam and reservoir project); Solem v. Bartlett, 465 U.S. 463 (1984) (holding that the Cheyenne River Sioux Tribe's reservation was not diminished); Rosebud Sioux Tribe, 430 U.S. at 584 (holding the Rosebud Sioux Tribe's reservation to have been diminished).

11. See, e.g., Derek Olson, Three Poorest U.S. Counties in South Dakota, Keloland.com (Jan. 23, 2012), http://www.keloland.com/NewsDetail6162.cfm?Id=0,126667.

12. See, e.g., Erik Eckholm, Gang Violence Grows on an Indian Reservation, N.Y. TIMES, Dec. 13, 2009, http://www.nytimes.com/2009/12/14/us/14gangs.html?pagewanted=all (describing violence on the Pine Ridge Reservation, which is home to the Oglala Sioux); Laura Sullivan, Lawmakers Move to Curb Rape on Native Lands, NPR, May 3, 2009, http://www.npr.org/templates/story/ story.php?storyId=103717296 (discussing rape on the Standing Rock Sioux Reservation).

13. See, e.g., Hoover, supra note 9, at 80-83, 89-90 (describing how implementation of the allotment policy led to extreme poverty among both the Indians of the Crow Creek Reservation and those of Pine Ridge); Tweedy, supra note 5, at 690-91 (linking lawlessness on reservations to the complex jurisdictional maze that governs criminal jurisdiction on reservations and that stems in significant part from the Supreme Court's concern about tribal jurisdiction on reservations containing large numbers of non-Indians and checkerboard land ownership patterns).

14. General Allotment Act, ch. 119, 24 Stat. 388 (1886). 
expectations under several distinct tests. Finally, Part IV ultimately concludes that any non-Indian expectations that may have existed regarding the disappearance of reservations and the consequent foreclosure of any possibility of tribal jurisdiction were, most likely, not justifiable.

\section{THE GENERAL ALLOTMENT ACT AND ITS IMPLEMENTATION}

The allotment period of federal Indian policy lasted roughly from the 1880 s through the $1920 \mathrm{~s},{ }^{15}$ and its centerpiece was the GAA. ${ }^{16}$ Enacted in 1887, the GAA - also known as the Dawes Act — was an attempt to forcibly assimilate Indians by breaking up tribal land holdings and distributing allotments of the land to individual Indians. ${ }^{17}$ The federal policy reflected in the GAA contemplated the eventual "transformation of Indian people into United States citizens with the corresponding disappearance of tribes and reservations." 18 Under the GAA, different amounts of acreage were distributed to individual Indians depending on family status and age, with larger amounts going to heads of household, smaller amounts going to single persons and orphans, and the smallest amounts going to non-orphaned minor children. ${ }^{19}$ The GAA established congressional policy regarding allotment and specified a general procedure. That policy was then implemented by individual statutes that pertained to specific reservations. ${ }^{20}$ The allotments were initially to be held in trust by the federal government for the benefit of the individual Indian owner for a period of twenty-five years, after which the Indian owner would hold the land in fee and be free to alienate it. ${ }^{21}$ But the pressure to create opportunities for non-Indians to acquire tribal lands led to multiple legislative and administrative attacks on this trust period. These attacks were implemented at various points until allotment efforts were formally terminated, and the allotment policy repudiated, in $1934 .^{22}$

\footnotetext{
15. See, e.g., Ann E. Tweedy, "Hostile Indian Tribes ... Outlaws, Wolves, .. Bears . . . Grizzlies and Things like That?" How the Second Amendment and Supreme Court Precedent Target Tribal Self-Defense, 13 U. PA. J. Const. L. 687, 709 (2011).

16. 24 Stat. 388.

17. See, e.g., Royster, supra note 2, at 9-10; see also Ann Tweedy, The Liberal Forces Driving the Supreme Court's Divestment and Debasement of Tribal Sovereignty, 18 BUFF. PUB. INTEREST L.J. 147, 189-90 (2000).

18. See Hoover, supra note 9 , at 63 (describing the prevailing federal policy in the $1880 \mathrm{~s}$ ); id. at 65 (describing the policy of the GAA).

19. $\S 1,24$ Stat. 388.

20. See, e.g., COHEN's HANDBOOK, supra note $4, \S 16.03[2][\mathrm{b}]$.

21. Id.

22. See, e.g., Hoover, supra note 9, at 79-81; Royster, supra note 2, at 10-12; see also COHEN's HANDBOOK, supra note 4, §16.03[2][c].
} 
Under the allotment policy, reservation lands that remained after individual Indians received their allotments were considered "surplus" lands and were, at least under initial plans, to be purchased from the tribes and then sold off to white settlers. ${ }^{23}$ While the GAA itself provided for tribal consent for the government's purchase of surplus lands and its subsequent sale of them to non-Indian settlers, Congress soon became frustrated with tribes' refusals to sell surplus lands in some cases and their demands for high prices in others. ${ }^{24}$ Accordingly, once the Supreme Court proclaimed Congress's right to unilaterally abrogate its treaties with Indian tribes in a now infamous 1903 case, Lone Wolf v. Hitchcock, ${ }^{25}$ Congress began to ignore the GAA's requirement of tribal consent for the sale of surplus lands. Congress similarly ignored the GAA's provision that such lands be purchased from tribes prior to being sold off to non-Indians, as well as the treaty provisions that protected tribes' land rights in many cases. ${ }^{26}$ Reservations that were opened to white settlement in the throes of this newfound congressional freedom included the Rosebud Sioux Reservation in South Dakota, the Crow Reservation in Montana, the Uintah and Ouray Reservation in Utah, the Flathead Reservation in Montana, the Wind River Reservation in Wyoming, the Spirit Lake Reservation in North Dakota, and the Standing Rock and Cheyenne River Sioux Reservations in South Dakota. ${ }^{27}$

By the time the allotment policy was repudiated in 1934, a total of 90 million acres of formerly tribal land had passed into non-Indian hands, and the total Indian land base had shrunk from 138 million acres to 48 million acres. ${ }^{28}$ These losses reflect sales of surplus reservation lands and loss of Indian allotments after issuance of fee patents to individual owners, with allotment losses occurring through tax foreclosures, mortgages, sales, and other means. ${ }^{29}$ The rates of loss on many reservations were even more

23. § 5, 24 Stat. 388; see also Royster, supra note 2, at 13 .

24. HoXIE, supra note 2, at 156; Royster, supra note 2, at 13.

25. Lone Wolf v. Hitchcock, 187 U.S. 553 (1903).

26. HOXIE, supra note 2, at 156-58; Royster, supra note 2, at 13-14.

27. HOXIE, supra note 2, at 156-58, 164-65. Note that the Spirit Lake Tribe was formerly called the Devil's Lake Tribe. See, e.g., The History and Culture of the Mni Wakan Oyate (Spirit Lake Nation), N.D. STUD., http://www.ndstudies.org/resources/IndianStudies/spiritlake/gov_contem porary.html (last visited June 27, 2012).

28. See, e.g., COHEN's HANDBOOK, supra note $4, \S 1.04$.

29. Royster, supra note 2, at 12-13. Notably, in light of failing agricultural economies and federal policy of forcibly decreasing Indians' dependence on the government, it appears that Indian allotment owners were often forced to sell their allotments to feed their families. Hoover, supra note 9, at 80-82 (describing the situation on the Crow Creek Reservation in the 1910s); see also id. at 89-90 (describing the Oglala Sioux's consumption of their livestock after their formerly thriving livestock industry was severely damaged by a storm in 1913 and after the Tribe faced decreased federal rations). 
striking than the composite number reflects. For instance, on the Cheyenne River Sioux Reservation, a full seventy-five percent of patentees lost their allotments within a span of a few years and, on other reservations, patentees suffered even greater rates of loss. ${ }^{30}$

Part and parcel of the idea that Congress could ignore both the more protective provisions of the GAA and treaty provisions protecting tribal property rights was a sentiment of blatant disregard of tribal property rights. While this sentiment was hardly a new product of the allotment era-indeed, it dates back to European colonization of North Ameri$\mathrm{ca}^{31}$-it was certainly in full force during the allotment period. ${ }^{32}$ For example, one congressman in 1896 rhetorically asserted that the Crow Tribe had no genuine right to its own land because the Tribe failed to use it in an economically beneficial way: "How . . . can [the Indian] have more than a possession of title simply by making moccasin tracks over it with his bow and arrow?"33 Then, in 1901, Senator Platt argued against ratifying an agreement with the Rosebud Sioux Tribe that would have compensated the Tribe for its surplus lands at the bargained-for rate of $\$ 2.50$ per acre by stating, "[W]hen we make an Indian tribe rich, . . . we delay its civilization." $34 \mathrm{He}$ further expounded that those Indians having "no money, no funds, no land, [and] no annuities" were "the easiest Indians in the country to civilize." ${ }^{35}$ His ideas were eventually implemented in the

30. See, e.g., 1 ENCYClOPEDIA OF AMERICAN IndiAn History 53 (Bruce E. Johansen \& Barry M. Pritzker eds., 2008).

31. See, e.g., Robert T. Anderson et AL., American Indian LaW: CASES \& Commentary 22-24 (2008).

32. See, e.g., Hoover, supra note 9, at 60 ("Most politicians representing white constituents in southern Dakota insisted that the opening of more land for settlement, by whatever means necessary, was essential for territorial development . . ., and they expressed no concern about the consequence for Indians." (emphasis added)); id. at 64 (describing federal officials' initial decision to circumvent the treaty requirement that three-fourths of the adult male citizens of the Sioux Nation consent to any treaty modification so as to satisfy white constituents); HoXIE, supra note 1, app. 81, at 3 (containing the March 1912 response of the Superintendent of the Cheyenne River Sioux Reservation to a questionnaire by the Commissioner of Indian Affairs in which the Superintendent stated that "white men . . . in the vicinity of this reservation care very little about the Indian, except for what gain they can make of him"); id. app. 81, at 5 ("There seems to be a very decided sentiment with the Grand Jury against indicting homesteaders for stealing Indian timber."); $i d$. (stating that "the feeling is that the Indian is game for anyone who can hit the mark"); $i d$. app. 81, at 13 (discussing a pending or recently passed bill and protesting that "[i]f the Congress . . . desired to make a present to the homesteaders in this country ... the price of the present should have come out of the public moneys and not out of the funds of [the Cheyenne River Sioux Tribe]"); see also Hoover, supra note 9, at 73 (tying non-Indians' allotment-era belief that tribes had no right to retain the lands that they were not cultivating to the views of a then-popular European philosopher, Emer de Vattel).

33. HOXIE, supra note 2, at 156 (alteration in original).

34. Id. at 156.

35. Id. at $156-57$. 
1904 Rosebud Act, which proclaimed, with a very limited exception, that "the United States shall in no manner be bound to purchase any portion of the land." $" 36$ Such ideas reflected a changing official view of tribal property: from that of a "birthright" of tribes and Indians to an understanding of tribal lands as simply "a part of the public domain"- a conception that took no account of tribal rights at all. ${ }^{37}$

The tribal rights disregarded during allotment included communally held tribal land rights and treaty rights, the latter qualifying as tribal property rights in their own right. ${ }^{38}$ Non-consensual allotments of tribal lands, under which land was forcibly taken from tribes and redistributed to individual Indians, constituted uncompensated takings of tribal lands because, while individual Indians received something of value, the tribe that owned the land did not. ${ }^{39}$ Similarly, non-consensual alienation of so-called surplus lands to white settlers also constituted an unconstitutional taking because of the lack of a permissible public purpose for the taking (in addition to the fact that some tribes did not receive fair market value). ${ }^{40}$

The taking of tribal lands as "surplus" was justified at the time by the notion that "Indians owned more land than they needed," and such takings have since been described as "a huge form of affirmative action for white people." ${ }^{41}$ While the comparison between sales of surplus lands and affirmative action for whites is a potent metaphor, it is an understatement given that extant real property rights in the United States have never been seen as an appropriate target for affirmative action programs. ${ }^{42}$ Rather, such takings are better understood as a form of persecution in line with other shameful acts in Western history, like the Canadian government's confiscation of many Japanese-Canadians' property after the bombing of

36. 33 Stat. 258 (1904); HoXIE, supra note 2, at 157.

37. HoxIE, supra note 2, at 161.

38. See generally Joseph William Singer, Lone Wolf, or How to Take Property by Calling It a "Mere Change in the Form of Investment," 38 TULSA L. REV. 37 (2002); see also Menominee Tribe of Indians v. United States, 391 U.S. 404, 413 (1968) (describing a tribe's treaty-protected hunting and fishing rights as property rights).

39. Singer, supra note 38 , at $44-45$.

40. Id. at $46-47$.

41. Id. at 47; see also Hoover, supra note 9, at 73-74 (describing non-Indians' allotment-era belief that Indians should not be able to retain more land than they could utilize); Kirkwood's Report, MINN. TRIB., Dec. 7. 1881, at 3 (advocating for allotment of Indian reservations generally and suggesting that "[t]he reservations set apart by treaty, or law, or executive order, have been usually many times larger than necessary ... for the support of the tribes placed thereon").

42. See, e.g., Gregory Camilli \& Kevin G. Welner, Is There a Mismatch Effect in Law School, Why Might it Arise, and What Would it Mean?, 37 J.C. \& U.L. 491, 494 (2011) (describing the three "main contexts" for affirmative action programs in the United States, both historically and currently, as contracting, higher education admissions, and hiring); accord Singer, supra note 38, at 47. 
Pearl Harbor ${ }^{43}$ and the historical denial of property rights to married women in the United States and England, ${ }^{44}$ to name only two.

\section{THE SUPREME COURT'S CURRENT RELIANCE ON THE GAA AND THE EXPECTATIONS IT ENGENDERED}

Despite the allotment policy's long-ago repudiation-and its constitutionally and morally troubling aspects - the Supreme Court continues to give it considerable weight in deciding issues of tribal jurisdiction over non-Indians. The Court also relies on the policy in deciding the related issue of whether allotment and the concomitant selling off of surplus lands to non-Indians legally effected a diminishment (or disestablishment) of a given tribe's reservation. ${ }^{45}$ As further discussed below, the Court's focus on allotment in these contexts constitutes an attempt to give effect to non-Indians' presumed justifiable expectations. ${ }^{46}$

Thus, we see the Supreme Court discussing the allotment policy and explicitly or implicitly relying on the fact that a reservation has been allotted in determining that a tribe lacks jurisdiction over nonmembers in various contexts. For example, in its "pathmarking" 47 tribal civil jurisdiction case, Montana v. United States, ${ }^{48}$ the Supreme Court relied on the fact that much of the land within the Crow Reservation was alienated to non-Indians through allotment and sale of surplus lands in holding that the Crow Tribe lacked authority to regulate non-Indian hunting and fishing on lands owned in fee by non-Indians:

The Secretary of the Interior and the Commissioner of Indian Affairs repeatedly emphasized that the allotment policy was designed to eventually eliminate tribal relations. . . . And throughout the congressional debates on the subject of allotment, it was assumed that the "civilization" of the Indian population was to be accomplished, in part, by the dissolution of tribal relations.

$\cdots$

There is simply no suggestion in the legislative history that Congress intended that the non-Indians who would settle upon alienated al-

43. See, e.g., Linda McKay-Panos, Post 9/11 Legislation and Policy in Canada-Neo-McCarthyism?, 54 U. NEW BRUNSWICK L.J. 178, 182 (2005). Similarly, in the United States, the federal and state governments inflicted many injustices on Japanese-Americans and Japanese nationals in the wake of the bombing. See, e.g., Oyama v. California, 332 U.S. 633 (1948).

44. See, e.g., 2-12 ThOMPSON ON REAL Property § 12.03 (David A. Thomas ed., 3d ed. 2011).

45. See, e.g., Frickey, supra note 6 , at 25, 38, 57; see also Tweedy, supra note 17, at 189-94 (discussing the Court's reliance on allotment in tribal jurisdiction cases).

46. Frickey, supra note 6 , at 25-26.

47. Strate v. A-1 Contractors, 520 U.S. 438, 445 (1997).

48. Montana v. United States, 450 U.S. 544 (1981). 
lotted lands would be subject to tribal regulatory authority. Indeed, throughout the congressional debates, allotment of Indian land was consistently equated with the dissolution of tribal affairs and jurisdiction. . . . It defies common sense to suppose that Congress would intend that non-Indians purchasing allotted lands would become subject to tribal jurisdiction when an avowed purpose of the allotment policy was the ultimate destruction of tribal government. And it is hardly likely that Congress could have imagined that the purpose of peaceful assimilation could be advanced if fee-holders could be excluded from fishing or hunting on their acquired property.

The policy of allotment and sale of surplus reservation land was, of course, repudiated in 1934 by the Indian Reorganization Act, 48 Stat. 984, at 25 U.S.C. $\S 461$ et seq. But what is relevant in this case is the effect of the land alienation occasioned by that policy on Indian treaty rights tied to Indian use and occupation of reservation land. ${ }^{49}$

Thus, while the Montana Court does not directly reference the expectations of non-Indian settlers, the Court bases its rejection of tribal jurisdiction largely on the intent of the repudiated allotment policy, and correctly points out (although the point is arguably irrelevant in the present day, given the policy's repudiation) ${ }^{50}$ that the Congress that enacted the policy would not have intended tribal jurisdiction over nonmembers to continue. Indeed, allotment is a common theme in Supreme Court cases regarding tribal civil ${ }^{51}$ and criminal jurisdiction ${ }^{52}$ from the Rehnquist era through the present. Moreover, the policy's effects, and the intent of specific allotment and surplus lands acts, are put even more directly at issue in reservation diminishment and disestablishment cases. ${ }^{53}$

The late Professor Phil Frickey has insightfully linked the Court's continued focus on allotment and its ongoing implementation of the policy to its concern for the justifiable expectations of non-Indian residents of

49. Montana, 450 U.S. at 559 n.9 (citations omitted).

50. See, e.g., Tweedy, supra note 17, at 191-94; Frickey, supra note 6, at 25-26.

51. See, e.g., Plains Commerce Bank v. Long Family Land \& Cattle Co., 554 U.S. 316, 328-32 (2008) (discussing allotment in a case involving a tribal court's jurisdiction to hear a tribal-law tort claim brought against a non-Indian-owned bank); Brendale v. Confederated Tribes \& Bands of the Yakima Indian Nation, 492 U.S. 408, 422-25, 436-40 (1989) (Stevens, J., plurality) (White, J., plurality) (discussing and relying on the allotment policy in a case regarding tribal on-reservation zoning authority).

52. Oliphant v. Suquamish Indian Tribe, 435 U.S. 191, 193 \& n.1 (1978) (discussing the effects of allotment in a case about tribal criminal jurisdiction over non-Indians); Frickey, supra note 6, at 36-38 (discussing Oliphant and how the allotment of the Suquamish Tribe's reservation apparently influenced the Court's decision).

53. See, e.g., Rosebud Sioux Tribe v. Kneip, 430 U.S. 584, $602-05$ (1977); see also Frickey, supra note 6, at 21-27, 48, 57 (discussing the Supreme Court's diminishment cases). 
Indian reservations. ${ }^{54}$ With this link as my starting point, I question the Court's inference that the allotment policy has given rise to justifiable expectations on the part of non-Indians. I first piece together from historical sources the expectations that might have been engendered by the allotment policy in general and the opening of specific reservations (such as the Cheyenne River Sioux Reservation) for non-Indian settlement. Second, using historical and legal sources, I question whether non-Indian purchasers' expectations - both as pieced together from historical sources and as constructed by the Supreme Court ${ }^{55}$ - should be considered justifiable. If these expectations were not justifiable, there would seem to be little reason to give them weight today. While the Court's focus on justifiable expectations has been criticized by other legal scholars, ${ }^{56}$ no one has yet taken an empirical look at allotment-era historical sources to determine what settlers' expectations might actually have been, nor has anyone used this type of historical information to analyze whether such settler expectations should be enforced.

\section{A. Methodology}

Because my focus was the Sioux Nation's land cessions, I primarily concentrated on Midwestern newspapers. I used online sources of historical news articles available from libraries, as well as from the Library of Congress's newspaper digitization project, Chronicling America. Additionally, I used some microfilm sources, including Saint Paul Pioneer Press and various South Dakota newspapers available at the South Dakota State Archives. With the electronic resources, I searched the dates comprising the allotment period broadly. With microfilm sources available from the South Dakota State Archives, I concentrated on important date ranges for the Cheyenne River Sioux Tribe, focusing primarily on the spring of 1908 through 1910, but also looking briefly at May and June 1875, May 1889, and June, July, and August 1904. ${ }^{57}$ I spent the bulk of my time at the South Dakota State Archives examining a local weekly

54. Frickey, supra note 6, at 21-22, 25-26, 38, 45, 49, 57.

55. I have criticized the Supreme Court's continued reliance on such presumed expectations in previous work. See, e.g., Tweedy, supra note 5, at $707 \&$ n.273 (suggesting that such expectations have been long-since fulfilled and that most of the purchasers who held them are likely deceased).

56. See generally Frickey supra note 6; Ezra Rosser, Protecting Non-Indians from Harm? The Property Consequences of Indians, 87 OR. L. REV. 175 (2008); Judith V. Royster, Montana at the Crossroads, 38 CONN. L. REV. 631 (2006).

57. Unfortunately, much of the microfilm I looked at from 1875 was partially illegible or completely illegible. My research assistant, Stef Hedlund, examined the St. Paul Pioneer Press microfilm.

Using the dates of other useful articles as guidelines, she looked at date ranges in the period 1908 through 1910. 
newspaper called the Ashton Chronicle because such a newspaper would have likely contained distilled information that would have been widely available to the citizens of South Dakota and nearby states and territories at the time. ${ }^{58}$

In addition to the news articles being both a source that settlers may have actually viewed and a representative source in the sense of being a repository of widely available information, those news articles that describe settler attempts to influence the government to take land from tribes also provide direct evidence of non-Indian participation in the violation of tribal land rights.

Analyzing historical census data in conjunction with statistics on historical newspaper circulation shows that a very significant percentage of the settler population read newspapers during the allotment era. For instance, according to the census, the total population of the United States in 1910 , including outlying possessions, was $101,115,487,{ }^{59}$ whereas the total newspaper circulation in 1909 was $58,505,000 .{ }^{60}$ Thus, the total circulation equaled about fifty-eight percent of the population during that time. This does not mean that fifty-eight percent of people read newspapers because one person may have read several newspapers, and, conversely, an entire family may have relied on a single copy of a newspaper. But the bare numbers do suggest that newspapers were widely read in 1909 and 1910. The data from earlier years is not as striking but still suggests significant readership. In 1900, for example, the total daily newspaper circulation was $15,102,000^{61}$ and the total population was $76,239,795,{ }^{62}$ which means that total circulation comprised about twenty percent of the population.

58. By current routes, Ashton is a little over one hundred miles from the Cheyenne River Sioux Reservation border; thus, it is in the same part of the state as the reservation but still at a distance that would have undoubtedly been viewed as considerable in the early 1900s. This degree of distance probably meant that Ashton residents were unlikely to have been privy to local information about the Tribe not widely available elsewhere, but that happenings of the reservation would have been close enough to have been of interest to them.

59. U.S. Bureau of the Census, 1 Thirteenth Census of the United States 22, tbl. 1 (1910), available at $\mathrm{http}: / / \mathrm{www} . c e n s u s . g o v / \mathrm{prod} / \mathrm{www} / \mathrm{abs} / \mathrm{decennial} / 1910 \mathrm{html}$.

60. U.S. BuREAU OF THE CENSUS, Historical Statistics OF THE UNited STATES: COlONiAL TIMES TO 1970 ch. R, ser. R 244-57 (1975), available at http://www2.census.gov/prod2/statcomp/ documents/CT1970p2-05.pdf.

61. Id. Because the only number for newspaper circulation in 1900 available from this source is for "Daily Circulation," the number for daily circulation has been used as the total circulation number. The total circulation of newspapers in 1900 , however, was probably significantly greater than the daily circulation number reflects.

62. William R. Merriam, U.S. Bureau of the Census, 1 Twelfth Census of the United STATES xix, tbl. 3 (1900), available at http://www.census.gov/prod/www/abs/decennial/1900.html. This total population number is comprised of the sum of the table entries for states and organized 
B. Direct Invocations of Non-Indian Purchasers' Justifiable Expectations

As discussed above, whenever the Court relies on allotment policies to decide a contemporary issue about tribal jurisdiction or reservation boundaries, it is implicitly giving effect to non-Indians' presumed justifiable expectations. ${ }^{63}$ The issue of justifiable expectations also comes up more directly in some jurisdiction and related cases, and it has often been a central theme in the diminishment cases.

For instance, the notion of justifiable non-Indian expectations was referenced in the Supreme Court's most recent case on tribal civil jurisdiction, Plains Commerce Bank v. Long Family Land \& Cattle Co. ${ }^{64}$ Writing for the majority in Long Family Land \& Cattle, which held that the Cheyenne River Sioux tribal court lacked jurisdiction over a non-Indian-owned, off-reservation bank in a tort action, Justice Roberts alluded to such allotment-era purchasers' justifiable expectations:

[I]t "defies common sense to suppose" that Congress meant to subject non-Indians to tribal jurisdiction simply by virtue of the nonmember's purchase of land in fee simple ... . If Congress did not anticipate tribal jurisdiction would run with the land, we see no reason why a nonmember would think so either. ${ }^{65}$

This language from Long Family Land \& Cattle evinces a concern that the original non-Indian purchasers of Cheyenne River Sioux reservation land were not on notice of the possibility that tribal jurisdiction would be asserted over them in the future - a possibility that was arguably incompatible with the prevailing federal policy of the time. Implicit in this concern is the notion that subjecting such purchasers to tribal jurisdiction would conflict with their justifiable expectations. In effect, the Court appears to treat the potential for tribal jurisdiction as a putative equitable servitude that cannot be enforced because of the original non-Indian purchasers' utter lack of notice. ${ }^{66}$

territories, Indian territories and reservations, and Hawaii; Alaska is excluded because it was not yet a territory. Id.; Alaska, ENCYCLOPEDIA AMERICANA (Grolier Online ed. 2012).

63. See Frickey, supra note 6, at 21-22, 25-26, 38, 45, 49, 57.

64. 554 U.S. 316 (2008).

65. Id. at 337 (citation omitted) (emphasis added).

66. The use of the phrase "run with the land" evokes the law of real covenants and equitable servitudes. See, e.g., 1-60 POWELl ON REAL Property § 60.01 (Michael Allan Wolf Desk ed., 2009); 7-61 THOMPSON ON REAL PROPERTY, supra note 44, $\S$ 61.02(b). For further illustrations of how Supreme Court Justices and scholars have linked tribal rights to real covenants and equitable servitudes, see Brendale v. Confederated Tribes \& Bands of the Yakima Indian Nation, 492 U.S. 408, 442 (1989) (Stevens, J., plurality) (characterizing tribal zoning authority in an area of the reservation that maintained its Indian character as an "equitable servitude"); Singer, supra note 38, at 46 (describing a tribe's treaty right that its lands not be taken by the government unless three-fourths of the adult male 
In another recent jurisdiction case, City of Sherrill v. Oneida Indian Nation, ${ }^{67}$ the Court more explicitly invokes non-Indians' justifiable expectations. ${ }^{68}$ City of Sherrill was in fact about local jurisdiction to tax a tribe's on-reservation property that had been reacquired by the tribe after a prolonged absence. Thus, tribal jurisdiction was not at issue in the case at all. But the Court's trepidation about the Nation's potential future assertion of regulatory jurisdiction was palpable and appears to have largely motivated the Court to rule against tribal tax immunity, and thus implicitly against any possible future assertions of tribal regulatory authority ${ }^{69}$-at least unless explicitly sanctioned by the federal government. ${ }^{70}$ In City of Sherrill, the Court specifically analogized the question of tribal tax immunity to reservation diminishment and noted that the "justifiable expectations" of non-Indians were similarly at issue in City of Sherrill's unusual context, given the State's "two centuries . . . of exercise of regulatory jurisdiction, until recently uncontested by" the Oneida Indian Nation. ${ }^{71}$ Indeed, the Court described the case as if it were actually about tribal jurisdiction:

$[T]$ he unilateral reestablishment of present and future Indian sovereign control, even over land purchased at the market price, would have disruptive practical consequences similar to those that led this Court in Yankton Sioux [a diminishment case] to initiate the impossibility doctrine. The city of Sherrill and Oneida County are today overwhelmingly populated by non-Indians. . . . A checkerboard of alternating state and tribal jurisdiction in New York State - created unilaterally at OIN's behest - would "seriously burde[n] the administration of state and local governments" and would adversely affect landowners neighboring the tribal patches. ${ }^{72}$

Putting aside the questionable negative cast in which the Court paints tribal jurisdiction over nonmembers ${ }^{73}$ (a portrayal that I have criticized in

members of the tribe agreed as "in effect a real covenant attached to the land"); see also Tweedy, supra note 17, at 164-65 (criticizing Justice Stevens's characterization in Brendale, 492 U.S. at 442 (Stevens, J., plurality), of tribal sovereignty as merely an attribute of tribal property rights).

67. City of Sherrill v. Oneida Indian Nation, 544 U.S. 197 (2005).

68. Id. at 215 .

69. Id. at 215-20. But see Rosser, supra note 56, at 209-17 (focusing on decreasing property values as the primary harm feared by non-Indians who stood to be impacted by a potential tribal success in City of Sherrill).

70. City of Sherrill, 544 U.S. at 220-21.

71. Id. at 215-16.

72. Id. at 219-20 (citations omitted).

73. See, e.g., Frickey, supra note 6, at 26 (elucidating the Court's negative assumptions about tribal jurisdiction over nonmembers based on an analysis of earlier cases); see also Rosser, supra note 
previous work ${ }^{74}$ ), this passage reflects the Court's preoccupation with the possibility of future tribal assertions of regulatory jurisdiction. Further, it reflects the Court's assumption that tribal regulatory jurisdiction would run counter to the expectations of non-Indians who purchased tribal lands after the State itself purchased them from the Oneida Nation in direct violation of federal law. ${ }^{75}$ Thus, at the risk of sounding melodramatic, in City of Sherrill, the Court is effectively having a nightmare about future assertions of tribal regulatory jurisdiction. And a large part of its nightmare involves disruption of non-Indians' justifiable expectations.

In tribal jurisdiction and related cases, then, the "justifiable expectations" of non-Indians are often raised obliquely through reference to the GAA. They also sometimes come up more directly, as in Long Family Land \& Cattle, in suppositions about whether non-Indian purchasers expected tribal jurisdiction to run with the land during the allotment era, and they are occasionally raised even more directly, as in City of Sherrill, where the Court explicitly relied on diminishment cases.

Furthermore, as stated above, justifiable expectations tend to be an explicit and central concern in cases about whether a given reservation has been diminished (or disestablished) as a result of the opening of its lands for settlement by non-Indians. ${ }^{76}$ Thus, in Hagen $v$. Utah, ${ }^{77}$ which held that the Uintah Reservation in Utah had been diminished as a result of Congress's having opened it for settlement by non-Indians, the Court states that a conclusion that the reservation had not been diminished "would seriously disrupt the justifiable expectations of the people living in the area," given Utah's longstanding practice of exercising jurisdiction and the demographics of the opened area, which was eighty-five percent non-Indian at the time of the decision. ${ }^{78}$ Likewise, the Court in Rosebud Sioux Tribe described South Dakota's longstanding exercise of jurisdiction over that reservation's opened area and the area's current demographics - namely, the fact that ninety percent of those living in the opened area were non-Indian-as having created "justifiable expecta-

56, at 189 (discussing "the Court's unfounded ease in repetitively assuming injury to non-Indians if the Oneida reasserted sovereignty over purchased land").

74. See, e.g., Tweedy, supra note 5, at 682-83.

75. See, e.g., Joseph William Singer, Nine-Tenths of the Law: Title, Possession \& Sacred Obligations, 38 CONN. L. REV. 605, 606-07 (2006).

76. See, e.g., Hagen v. Utah, 510 U.S. 399, 421 (1994); Rosebud Sioux Tribe v. Kneip, 430 U.S. 584, 604-05 (1977); Frickey, supra note 6, at 21 (discussing Hagen); see also id. at 25-26 (arguing that a concern with justifiable expectations is generally at work in the Court's diminishment jurisprudence).

77. 510 U.S. 399 .

78. Id. at 421 . 
tions" that the Court should not disrupt. ${ }^{79}$ Thus, a concern with non-Indians' "justifiable expectations" motivates the Court in both the diminishment and tribal jurisdiction cases, although the concern is more often explicitly stated in the diminishment context.

\section{SETTLER EXPECTATIONS AND THEIR JUSTIFIABILITY}

\section{A. The Timeframe of Expectations}

The Court has been inconsistent in its approach to the timeframe within which it assesses expectations. In tribal jurisdiction cases, such as Montana and Long Family Land \& Cattle, the Court looks back to the era of allotment to assess what it imagines might have been the initial non-Indian purchasers' justifiable expectations. ${ }^{80}$ In the diminishment cases, however, the Court appears to be looking more to the expectations of contemporary non-Indian reservation residents, or at least including their presumed expectations in its assessment. For example, in Hagen, the Court refers to "the justifiable expectations of the people living in the area," 81 and, in Rosebud Sioux Tribe, the Court asserts less precisely that the State's "longstanding assumption of jurisdiction [over the area] ... has created justifiable expectations." 82 Thus, the Court alternates between eras depending on the issue at hand when it assesses justifiable expectations.

Admittedly, trying to determine non-Indian reservation residents' likely expectations from the allotment era through the present would be a tall order. But from the standpoint of notice, it would seem to be the initial non-Indian purchasers - not the current non-Indian residents of a reservation - whose expectations should be assessed. The original non-Indian purchasers of surplus lands during allotment were the ones who could most plausibly claim to have changed their positions in reliance on allotment. In other words, the Court should focus on the expectations of those who bought and settled land allegedly based in part on the mistaken view that the reservations and the tribes who governed them were about to disappear forever.

But federal policy had changed dramatically by 1934 . As of 1934 , when Congress enacted the Indian Reorganization Act, ${ }^{83}$ non-Indian

79. Rosebud Sioux Tribe, 430 U.S. at 604-05.

80. See also Oliphant v. Suquamish Indian Tribe, 435 U.S. 191, 193 \& n.1 (1978) (discussing allotment in a case concerning tribal criminal jurisdiction).

81. Hagen, 510 U.S. at 421.

82. Rosebud Sioux Tribe, 430 U.S. at 604-05.

83. 25 U.S.C. $\S \S 461-479$ (2012). 
buyers were on notice that the federal government had put an end to allotment and would actively support the governance efforts of tribal governments. ${ }^{84}$ And while Congress entered another - this time brief-period of hostility toward tribal governments in the late 1940s and 1950s, ${ }^{85}$ this period should be viewed as having little relevance to issues of tribal jurisdiction because, in 1948, Congress had explicitly separated the issue of reservation land ownership from tribal jurisdiction by defining "Indian country" to include all lands within the boundary of any reservation, regardless of land ownership - a definition that still stands today. ${ }^{86}$ Moreover, Congress currently supports tribal self-determination and has consistently done so since the 1970s. ${ }^{87}$ Even the Supreme Court recognizes the possibility of tribal jurisdiction over nonmembers in recent opinions and sometimes upholds it. ${ }^{88}$ Thus, land buyers and others who have acquired, or simply entered reservation land, in the past few decades were on notice of the possibility of tribal jurisdiction. Only allotment-era buyers, then, were arguably under a congressionally supported misapprehension about the future of tribal governments and the potential jurisdictional implications of that future. Therefore, I focus my analysis primarily on historical sources from the allotment era to piece together non-Indian purchasers' expectations. Additionally, I examine newspaper articles regarding a land cession that occurred just before the allotment era, namely the taking of the Black Hills.

\section{B. What Historical Sources Suggest About Non-Indian Expectations}

The numerous historical newspaper articles I looked at from the allotment era and the smattering from the preceding decade present a mixed view of the sale of surplus lands and the allotment policy generally. As shown below, many of the articles are geared toward encouraging settlers to buy surplus land on reservations and thus focus on the type of land available, rather than on how it was obtained from the tribes to whom it

84. See Frickey, supra note 6, at 15-16; Royster, supra note 2, at 16-18, 62. Apparently, occasional exceptions were administratively made to the Indian Reorganization Act's firm prohibition on further allotments, although such allotments were presumably held in trust indefinitely, and therefore were not alienated to non-Indians. See Hoover, supra note 9, at 88; see also COHEN's HANDBOOK, supra note 4, § 15.07[1][a] (discussing the Indian Reorganization Act).

85. See, e.g., Royster, supra note 2, at 18 (discussing the Termination Period).

86. See, e.g., Solem v. Bartlett, 465 U.S. 463, 468 (1984) (discussing 18 U.S.C. § 1151). The Termination Period alluded to here would undoubtedly have relevance in specific cases, namely for those tribes whose relationships with the federal government were terminated during that era.

87. See, e.g., Royster, supra note 2, at 66.

88. See, e.g., Tweedy, supra note 5, at 676-83 (discussing several of the Supreme Court's recent cases on tribal civil jurisdiction); see also United States v. Lara, 541 U.S. 193 (2004) (upholding tribal criminal jurisdiction over a nonmember Indian). 
belonged. Some of the news stories paint a rosy picture of Indians' and tribes' purported agreement with the allotment policy and of the benefits Indians supposedly obtained as a result of the policy, both of which are generally in conflict with more reliable historical sources from that era. Many articles, however, reflect a paternalistic, superior attitude toward Indians, which appears to reflect the prevailing white attitudes of the day, suggesting some complicity on the part of settlers in the disregard of tribal rights. ${ }^{89}$

More relevantly, several news articles note that the lands at issue were treaty-protected tribal lands and therefore comprised federally recognized property rights. And quite a few articles describe the character of the Indians on the given reservations, which undoubtedly would have put buyers on notice that they were moving onto a reservation and would thus be in somewhat close proximity with Indians, and, from this information, they could have reasonably inferred that such proximity might affect governance and jurisdictional issues. ${ }^{90}$ Additionally, some articles describe settler movements to advocate for the opening of reservations, ${ }^{91}$

89. See supra note 32 and sources cited therein; see also Rosser, supra note 56, at 216-18 (questioning the innocence of current non-Indian residents and past purchasers of land within the Oneida Indian Nation's reservation, of which the Nation had been unlawfully dispossessed, and arguing that non-Indians' lack of innocence is relevant to the validity of their expectations).

90. See, e.g., Notes, CHI. Livestock World, Aug. 4, 1904, at 6 (discussing the opening of the lands of the Spirit Lake Tribe and describing tribal members in favorable terms); New Lands for Settlers.; The Great Sioux Reservation in Southern Dakota to Be Thrown Open, N.Y. TIMES, Feb. 9, 1883, http://query.nytimes.com/gst/abstract.html?res=FA0D12FE3C5511738DDDA90994DA405B8 384F0D3 (noting that the settlers "will be surrounded by" Indians after the dismantling of the Great Sioux Reservation).

91. See, e.g., Kirkwood's Report, supra note 41 ("Our people in their march westward have surrounded these reservations, and seeing in them large tracts of fertile land withheld from the purpose for which they believe it was intended - cultivation - have called upon the executive and legislative departments to make new treaties, new laws, and new orders, and these calls have generally been heeded."); Open Every Acre of Reservations: Gamble Bill Does Not Include Enough, It Is Urged: Resolution Asks That Strip Along the Missouri Be Included in the Opening of the Cheyenne River and Standing Rock Indian Reservation-Residents Are Opposed to It., ST. PAUl PIONEER PRESS, Jan. 26. 1908, at 10 [hereinafter Open Every Acre of Reservations]; see also Hoover, supra note 9, at 63 (describing the demands of a group of territorial residents who met in Deadwood, South Dakota in May 1882 and urged that " "[s]ecuring the opening of the Sioux Reservation to actual settlers, at the earliest possible time,' ... would be most beneficial to people in their quest for statehood" and noting that their statement was "[t]ypical" during that time period).

Similarly, it appears that it was common for individuals and families to attempt to illegally appropriate Indian lands on a piecemeal basis during the allotment era. See, e.g., LAURA InGALLS Wilder, LitTle House ON THE PRAIRIE 233-34 (1st ed. 2003) (describing an incipient (and abandoned) plan on the part of various tribal groups to drive whites out of Indian country); No School for 'Squatters.'; Peculiar Situation in 'Sooner' Town in Tripp County., POTTER CounTY News \& COURIER, June 11, 1908, at 6 (describing squatters who took up residence on the Rosebud Reservation before it was opened); Otis' Days Numbered: Confidently Asserted That the President Will Soon Make a Change: The General Has Been Carrying Measures With Too High a Hand., MinN. TriB., Sept. 26, 
and these movements clearly point toward settlers' complicity in applicable cases in the taking of tribal lands. Finally, and perhaps most importantly, several articles report tribal disagreement with individual reservation openings.

\section{The Appropriation of the Black Hills}

In 1877 , before the allotment era had officially begun, the federal government violated its treaty with the Sioux Nation and forcibly took the Black Hills, a sacred portion of the Great Sioux Reservation. This expropriation was motivated by the discovery of gold in the area and the consequent great pressure from non-Indians to open it for non-Indian settlement. ${ }^{92}$ In the words of one scholar, title to the Black Hills was wrested from the Sioux Nation through a federal policy "of open warfare," 93 which included threats to the Indians that "death and starvation [would] stare [them] in the face" should they refuse to cede their sacred lands. ${ }^{94}$ The Court of Claims branded the expropriation of the Black Hills as probably the most "ripe and rank case of dishonorable dealings" to "be found in our history." 95

Newspaper articles of that era confirm that the public understood the likelihood that Sioux rights would be violated in the taking of the Black Hills. Indeed, in some cases, the articles' authors seem to support the taking and the concomitant violation of tribal property rights. For example, a Chicago Daily Tribune article from June 1875 describes the tone of the Commissioner of Indian Affairs in negotiating with the Nation as "very blunt and forcible." "Fu Furthermore, the article explains that the Commissioner told the tribal negotiators that if gold were to be discovered in the Black Hills, "they would be forced to give up their title to the Black

\footnotetext{
1899, at 1 (discussing the fact that settlers were building on lands within the Leech Lake reservation prior to its being "offered for sale," despite a contrary order of the Secretary of the Interior and also noting that "[i]t is not expected that the [Interior] department will take any action to eject these parties"); see also infra note 200 (describing squatters' actions on Pueblo lands).

92. See generally Sioux Nation of Indians v. United States, 601 F.2d 1157 (Ct. Cl. 1979), aff'd 448 U.S. 371 (1980); see also Hoover, supra note 9, at 60 (noting that the treaty provision requiring that three-fourths of all adult male Sioux citizens agree to any future cession of treaty-protected land "had been ignored" in the United States' acquisition of the Black Hills).

93. New Holy, supra note 9, at 327.

94. Id. at 329; see also Tweedy, supra note 15, at 733-34 (discussing the federal government's threat of starvation to the Sioux Nation).

95. Sioux Nation of Indians, 518 F.2d at 1302.

96. Washington. The Sioux and Cheyennes Bid Good-Bye to the Capital. The Government's Ultimatum Made Clear to Them in Brief but Forcible Terms, CHI. DAILY TRIB., June 6, 1875, at 13 [hereinafter CHI. DAILY TRIB., June 6, 1875].
} 
Hills." "97 The term "force" was apparently used in the strongest sense of the word, for the article begins with a prediction "that the Sioux, the troops, and the gold pioneers are likely to soon exchange shots." article further notes that " $[t]$ he Government expects that ... the Sioux may be compelled to relinquish their treaty right to what are supposed to be the demands of advancing civilization." 99

Another Chicago Daily Tribune article from the previous day reports that a Sioux leader, Spotted Tail, first stated that "it was not worthwhile talking about the Hills now, as they [the Sioux Nation] would demand a very high price." 100 When the Secretary of the Interior insisted upon continuing the discussion, weakly noting that, if gold were discovered in the Black Hills, "it would be impossible to keep the white people out," Spotted Tail accused the federal government of attempting theft: "Spotted Tail said the Great Spirit had told him never to steal anybody's country without paying for it. If you had the same sense of right, we could get along well enough." "101 A similar, but very abbreviated, article in a South Dakota newspaper from the previous week also reports on Sioux leaders' objections to ceding the Black Hills, albeit in much less detail. ${ }^{102}$

These three news stories convey to the public the government's disregard for Sioux property rights, accurately foreshadow the coercive character of the eventual sale, and communicate the important information that a treaty between the Tribe and the federal government - a property right in its own right - stood to be abrogated. One gets a sense in reading the articles that the Sioux Nation's property rights were not regarded as entitled to the same respect as whites' property rights. At a minimum, any readers of the articles in the Chicago Daily Tribune, the South Dakota newspaper article, or similar articles in other papers who went on to purchase land in the Black Hills were on notice of the probability that the land was ultimately acquired from the Sioux Nation by less than honorable (and, indeed, legally suspect) means.

97. Id. For an excerpt of another, more general article from this timeframe evincing a disregard of tribal property rights, see RiCHARD SLOTKIN, GUNFIGHTER NATION: THE MYTH OF THE FRONTIER In Twentieth Century America 40-41 (1992) (quoting Our Indian Policy, N.Y. World, Jan. 18, 1874 , at 4$)$.

98. CHI. DAILY TRIB., June 6, 1875, supra note 96.

99. Id. (emphasis added).

100. Washington. The Sioux Warriors Fold Their Blankets and Steal Away. Spotted Tail Becomes Irate and Expresses his Views in Un-courtly Terms. He Hints the Government is Bound to Rob Them of Their Lands, CHI. DAILY TRIB., June 5, 1875, at 5 [hereinafter CHI. DAILY TRIB. June 5, 1875].

101. CHI. DAILY TRIB., June 5, 1875, supra note 100.

102. The Past Week. Domestic Intelligence. Washington, DAKOTA RePUBLICAN, June 3, 1875, at

1. 
Another South Dakota newspaper article from the same timeframe demonstrates complicity on the part of the people of South Dakota in the taking of the Black Hills, although it is arguably less direct regarding the means to be used than the two Chicago Daily Tribune articles. After recounting the progress of the non-Indians in the Territory of Wyoming and the State of Nebraska in convincing the government to abrogate tribal rights, the article states that the people of Dakota "merely ask" the government to use "all honorable and the most expeditious means to abrogate the treaty ... and extinguish the Indian title to as much of the Black Hills as is supposed to abound in mineral wealth." 103 Part of the article is a reproduction of a document filed on their behalf with the Secretary of the Interior seeking a governmental appropriation of the Black Hills. ${ }^{104}$

This article demonstrates that the settlers were, at least to some degree, complicit in the eventual abrogation of the treaty, although arguably the request for use of honorable means suggests some measure of compunction as to the methods of abrogation. ${ }^{105}$ The article also recognizes the Sioux Nation's treaty right to the Black Hills as a legal obstacle to settler acquisition.

But not all articles on the appropriation of the Black Hills were as descriptive as the four described above. For example, an article in a Minnesota newspaper in 1876 recounted that a treaty had been "recently made with the Indians at the Red Cloud Agency" and "ratified by those of the Spotted Tail Agency" by which "the Black Hills reservation is relinquished to civilization." 106 The article makes no mention of the fact that the treaty had garnered nowhere near the number of individual Sioux signatures necessary to make it legally binding upon the Sioux Nation ${ }^{107}$ or of the coercive methods used to procure signatures. But the article does report the meager consideration that the Nation received for the cession: "certain annuities, rations, transportation, and assistance in farming and house building." 108 A reader could certainly infer from that information that the Sioux had made a very poor bargain. And readers who were aware

103. The Black Hills. Pennington and Kidder. What They Ask in the Name of Dakota, Touching the Black Hills, DAKOTA REPUBLICAN, June 3, 1875, at 2.

104. Id.

105. For a shockingly virulent opinion piece also from June 1875 that completely dehumanizes Indians, see The Indian Question, DAKOTA REPUBLICAN, June 17, 1875 at 2. While this article does not explicitly mention Indian property rights or the Black Hills, it suggests that tribal rights in general are mere products of government pampering, that Indians should be subject to the same laws as everyone else, and that, if they don't cease “their fiendish" ways, Indians should be exterminated. Id. 106. WinONA DaILY REPUBLICAN, Oct. 2, 1876, at 2.

107. Francis Paul Prucha, 2 The Great Father: The United States Government \& The AMERICAN INDIANS 632-33 (1984); New Holy, supra note 9, at 328.

108. WiNONA DAILY REPUBLICAN, Oct. 2, 1876, supra note 106. 
of the Sioux's prior resistance to selling the lands-likely a large percentage of people - could logically infer that foul play was a strong possibility.

Later, allotment-era news articles that address the taking of the Black Hills affirm that the Sioux understood their lands had been wrongfully taken. ${ }^{109}$ Thus, non-Indian buyers of lands in the Black Hills who purchased lands even later during the allotment-era would have been on direct notice of a potential tribal claim of some right to the land.

\section{The Dismantlement of the Great Sioux Reservation}

Despite the recent appropriation of the Black Hills, pressure to make further inroads onto Sioux lands continued in the $1880 \mathrm{~s} .{ }^{110}$ While early bills providing for the opening of the Great Sioux Reservation failed-largely because of concerns about lack of tribal consent ${ }^{111}$ — eventually the required number of adult males signed the agreement to cede over 9 million acres of land and divide themselves onto several smaller reservations. ${ }^{112}$ However, the signatures were coerced: the Sioux were told that, if they did not sign, their land would be taken on less favorable terms. ${ }^{113}$ More aggressive tactics included jailing opponents of the cession and forbidding influential leaders, such as Sitting Bull, from speaking out publicly against the proposal. ${ }^{114}$

Moreover, the federal government's side of the agreement was not carried out. Although the Sioux living in the ceded area were guaranteed allotments, to be chosen prior to the opening of the reservation, in fact, the reservation was opened to non-Indian settlement before any allotments were taken, and other provisions of the agreement were also broken. ${ }^{115}$

109. See, e.g., Black Hills Country, Daily ARgus Leader, May 26, 1908, at 4; Sioux Go Out for Uncle Sam's Scalp of Gold, CHI. DAILY TRIB., May 7, 1923, at 1; Sioux Indians Meet in Big Council: Close Corporation Formed on the Six Reservations to Push Claims Against General Government, AsHTON CHRON., Aug. 12, 1904, at 5.

110. See, e.g., PRUCHA, supra note 107, at 633; Hoover, supra note 9, at 62-63.

111. PRUCHA, supra note 107, at 634-38; Hoover, supra note 9, at 64.

112. See, e.g., PRUCHA, supra note 107, at 639; John S. Harbison, The Broken Promise Land: An Essay on Native American Tribal Sovereignty over Reservation Resources, 14 STAN. ENVTL. L.J. 347, 353 (1995); Hoover, supra note 9, at 65, 68.

113. PRUCHA, supra note 107, at 638-39.

114. Hoover, supra note 9, at 66-67. In fact, Sitting Bull's death was related to his opposition to the cession, and the federal government's fear of him and his followers caused not only his own death but the many "senseless killings" of Wounded Knee. Id. at 67-69.

115. PRUCHA, supra note 107, at 638-40; see also Agreement with the Sioux, March 2, 1889, § 13 in Vine DELORIA, JR. \& RAYMOND J. DEMAILle, DOCUMENTS OF AMERICAN INDIAN DiPLOMACY: TREATIES, AGREEMENTS, \& CONVENTIONS, 1775-1979, 310 (1999). 
Tribes eventually received an average of fifty-seven cents per acre for lands relinquished under the 1889 Agreement. ${ }^{116}$

The news articles addressing the prospect of breaking up the Great Sioux Reservation before the opening actually occurred generally reflect lack of tribal agreement with the federal plan to sell off part of the reservation. ${ }^{117}$ And one article in particular acknowledges that the consent to be procured would be "nominal[]" and that all parties understood in advance "just how it [was] . . to end." 118 Additionally, in one of the articles, the chairman of the commission appointed by President Harrison to procure the Sioux Nation's consent to the opening describes the upcoming negotiations in brutal, racialized tones: "We will start tomorrow night or Thursday morning and I hope when I come back I will have my scalp with me." 119 Such a statement by the man who was one of the lead negotiators reveals deep governmental hostility toward the Sioux and accurately suggests that the meetings would not be true negotiations at all.

In a similar vein, other news articles of that period evidence a lack of respect for the Sioux's property rights. For example, one early opinion piece mockingly describes those who support the Sioux in protecting their land and other rights:

116. Hoover, supra note 9 , at 70.

117. See, e.g., Cash, Not Cattle. Sioux Indians Want Money for Their Lands, Not Broken Down Livestock, WinONA DAILY REPUBLICAN, May 28, 1889, at 1 (describing the Sioux Nation's opposition to one of the early bills); Indians Can't Agree. The Sioux Chiefs at Washington Split into Two Factions, MINN. TRIB., Oct. 15, 1888, at 3 ("It is said that they [the Sioux] are almost hopelessly split among themselves, and that there is slight prospects [sic] of their being able to unite on any proposition."); New Lands for Settlers.; The Great Sioux Reservation in Southern Dakota to Be Thrown Open, supra note 90 (reporting that the Sioux and other tribes were being "forc[ed] . . into contracted areas" as a result of the opening of reservation lands for settlement, but reciting that treaties had been made with each of the Sioux bands for the proposed cession); To Visit the Sioux, MinN. TRIB., May 28, 1889, at 1 (stating that the Sioux "are unwilling to sell the central strip of their reservation"). But see A Sioux Delegation. Indians Appointed to Confer with the Commissioners, DAILY ARGus LeAdER, May 20, 1889 (noting that the Indians at the Cheyenne Agency had decided through their council to negotiate with the government's commission and that "a large majority" of council members appeared to favor accepting the government's proposal); The Sioux Reservation. Little Doubt that the Indians Will Sign the Treaty, MINN. TRIB., May 12, 1888, at 9 (stating that "[m]ost of the Indians, at least those of the Cheyenne agency, are anxiously awaiting to have the deal closed up and off their hands"). However, even the May 12, 1888 article contains hints that the Indians' amenability is coerced; one Sioux man is quoted as saying " $[\mathrm{w}]$ hile the provisions of the bill are not in accord with our views in every particular, they are good and all that we could desire, and we must accept them as they are." The Sioux Reservation. Little Doubt that the Indians Will Sign the Treaty, supra (emphasis added).

118. The Dakota Oklahoma. The Next Big Rush Will Be into the Sioux Reservation., DAILY ARGUS LEADER, May 28, 1889. This article also notably states that "the laws of Dakota" would "be in force [in the area] as soon as the Indians vacate." Id.

119. To Visit the Sioux, supra note 117. 
These are the men ... that are afraid to have the rations diminished for fear the Indian will go hungry. They oppose the giving of lands in severalty for fear poor Indians will thus lose title to the big tract which he holds as a reservation.

If the bill needs any amendments to make it more effective in breaking up the reservation and leading to the abolishment of all reservations ... then let the amendments be made. ${ }^{120}$

Such articles demonstrate that those following the government's attempt to obtain Sioux lands would have known of tribal opposition. Moreover, these articles also suggest the existence of a significant amount of public sentiment opposed to respecting the Sioux's property rights. ${ }^{121}$ Otherwise, the news commentator and commission chairman would most likely have been more reserved in their remarks. Moreover, while none of the articles I found directly described the coercive tactics used to secure the cession, several articles of the era conveyed the coercive character of the negotiations.

Not all of the articles published before President Harrison proclaimed the Sioux Nation's acceptance of the opening in February $1890^{122}$ are as revealing, ${ }^{123}$ however, and many of the articles published afterward are mixed. For instance, an 1895 article simply announces that a large portion of the reservation is "now opened for settlement . . under an act passed in 1889,", 24 without mentioning anything about the Sioux Nation's response to this development. By contrast, however, an 1890 article, spe-

120. The Sioux Reservation Bill, FARM, FIELD \& STOCKMAN, Jan. 1, 1887, at 8. Farm, Field and Stockman was a Chicago-based paper with a circulation of 52,275 in 1888. N.W. AYER \& SON'S AMERICAN NEWSPAPER ANNUAL 85 (1888).

121. Accord Hoover, supra note 9, at 73-74 (describing a prevailing non-Indian view during the allotment era that generally people did not have the right to more land than they could utilize and that Indians "had no right to keep any land of their own out of [agricultural] production"); Hoxie, supra note 1, app. 81, at 3 (containing the March 1912 response of the Superintendent of the Cheyenne River Sioux Reservation to a questionnaire by the Commissioner of Indian Affairs in which the Superintendent stated that "white men . . . in the vicinity of this reservation care very little about the Indian, except for what gain they can make of him"); id. app. 81, at 5 ("There seems to be a very decided sentiment with the Grand Jury against indicting homesteaders for stealing Indian timber."); $i d$. (stating that "the feeling is that the Indian is fair game for anyone who can hit the mark").

122. PRUCHA, supra note 107, at 640; see also Proclamation No. 9, 26 Stat. 1554 (Feb. 10, 1890).

123. See, e.g., A Sioux Delegation. Indians Appointed to Confer with the Commissioners, supra note 117 (noting that the Indians at the Cheyenne Agency had decided through their council to negotiate with the government's commission and that "a large majority" of council members appeared to favor accepting the government's proposal); The Sioux Commission, DAILY ARGUS LEADER, May 22, 1889 , at 1 (reporting on the Sioux Commission's preparations for negotiations with the Sioux Nation); Where They Will Start In, DAILY ARguS LeADER, May 22, 1889, at 1 (reporting that the Sioux Commission will begin at Lower Brule).

124. Land for Settlement, WINONA DAILY REPUBLICAN, Feb. 12, 1895, at 1. 
cifically about the Cheyenne River Sioux, states that they "declined to give up their land to settlement when the question was put to a vote of the entire Sioux nation about a year ago." ${ }^{25}$ It further reports that the Cheyenne River Sioux view the opening of the area of the reservation in which they live as "unjust and cruel.", 26 After commenting dismissively about tribal grievances generally, the article states that "it does seem that this band of Sioux has just and proper cause for grievance against the Government." 127

Collectively, these articles show that, while ordinary readers may not have been on notice of the particular tactics used against the Sioux in effecting the opening of the reservation, many such readers probably were aware that the Sioux opposed the plans during most of the negotiation process, and at least some of them had information suggesting the Nation's assent was likely only nominal.

\section{The Rosebud Opening}

Before addressing the 1908 allotment and opening of the Cheyenne River Sioux Reservation in depth, it is worthwhile to briefly examine the slightly earlier allotment and opening of a related tribe's reservation - that of the Rosebud Sioux. As described above, the taking of the Black Hills occurred in 1877. And in 1889, Congress authorized millions more acres of Sioux reservation land to be taken and sold off to whites and the divi-

125. The Sioux of South Dakota, FrANK LESLIE'S ILLUSTRATED NEWSPAPER, Dec. 20, 1890, at 372.

126. Id.

127. Id. Frank Leslie's Illustrated Newspaper was a literary newspaper published in New York City that had a circulation of 33,450 in 1880 . N.W. AYER \& SON'S AMERICAN NEWSPAPER ANNUAL 52 (1880), available at http://lcweb2.loc.gov/diglib/vols/loc.gdc.sr.sn91012091.00123398683/page turner.html? page $=58 \&$ size $=800$. While this was certainly a large circulation for the time, the fact that the paper was published in New York (and thus quite far from the Sioux's homeland) probably made it less likely that potential non-Indian land buyers would read the article, although allotment-era settlers did sometimes come from great distances, including New York City, to purchase Indian lands in South Dakota. See, e.g., 1,800 Register for New Lands: First Hour After Midnight Crowd Swarms Booths for South Dakota Reservations. First Woman is Gopher: Minnesotans Among First to Hear Call-Two to Marry If Either Is Lucky, DAILY PIONEER PRESS, Oct. 4, 1909, at 1 [hereinafter 1,800 Register for New Lands] (reporting that settlers seeking land on the Cheyenne River Sioux and Standing Rock Sioux Reservations came from as far away as Pennsylvania); Thousands File on the Rosebud: Many Wait All Night in Driving Rain to Register-Good Order in Crowds at All Filing Places, AsHTON CHRON., July 15, 1904, at 4 (reporting that the first settler to file at Bonesteel for Rosebud lands was a man from New York City and that "[e]xcursions from Eastern points [of settlers hoping to acquire Rosebud lands] will reach this city [Yankton] to-morrow"); see also Winners of Government Land: First Luck in Rosebud Drawing Falls to Nebraska Veteran-First One Hundred Lucky Ones, AshTON CHrON., Aug. 5, 1904, at 7 (reporting on the locations and names of the first one hundred settlers who succeeded in a lottery for Rosebud land; states represented included Iowa, Oklahoma, Missouri, South Dakota, Illinois, Kansas, and Wisconsin). 
sion of the Sioux people onto smaller reservations, including the Rosebud Sioux Reservation and the Cheyenne River Sioux Reservation.

The Rosebud reservation in turn was allotted in the early 1900s, and surplus lands were authorized to be sold to non-Indian settlers - without having been purchased from the Tribe-in 1904. ${ }^{128}$ Indeed, the Rosebud reservation was the first victim of Congress's newfound power to take treaty-protected tribal land without tribal consent - a power that stemmed from the Supreme Court's decision in Lone Wolf. ${ }^{129}$ In 1977, the Supreme Court declared that the portion of the Rosebud Reservation that had been sold off to non-Indians as surplus lands - the opened portion-was no longer part of the reservation. Thus, the reservation was held to have been diminished, based in large part on non-Indians' presumed justifiable expectations. ${ }^{130}$

Compared to the lands of the Cheyenne River Sioux, those of the Rosebud Sioux were much more fertile. And this fertility led settlers to vigorously pursue the Rosebud lands, ${ }^{131}$ while the later Cheyenne River Sioux opening did not generate a high percentage of settler filings. ${ }^{132}$ The large influx of non-Indian settlers onto the Rosebud reservation was part of the Court's rationale for holding the Rosebud reservation to have been

128. HoXIE, supra note 2, at $156-57$.

129. Id. While the Sioux Agreement of 1889 purported to authorize the smaller reservations to be allotted in the discretion of the President, Agreement with the Sioux, supra note 115, at 309, § 8, it provided merely that the government could negotiate for the "purchase and release" of any surplus lands after such allotments. Id. at $310, \S 12$. Moreover, since the Sioux Nation's approval of the Sioux Agreement was obtained by coercive tactics, its purported authorization to allot the reservations is subject to serious legal question, and the Sioux Nation's earlier treaty with the government should instead control.

130. See generally Rosebud Sioux Tribe v. Kneip, 430 U.S. 584, 604-05 (1977).

131. See, e.g., HoxIE, supra note 1, at 47-48; Hoover, supra note 9, at 85; see also An Iowan's View of Tripp County: Son of Lafe Young Writes of the Rosebud Country, Thinks Opening in October, NORFOLK WKLY. NEWS-J., Aug. 7, 1908, at 2 (describing the portion of the Rosebud Reservation that had already been opened and the portion yet to be opened as "an agricultural paradise" and noting of the upcoming opening of Rosebud lands that "[i]t is expected that crowds will exceed that [sic] of former openings"); Rosebud Section of South Dakota Much Benefitted: Recent Rains Help the Prospect of Good Crops in Tripp and Gregory, ASHTON CHRON., July 22, 1910, at 6 (describing favorable crop conditions on the opened portion of the Rosebud Reservation); Squatters File on Tripp Lands: Make Midnight Rush and Form in Lines for Homesteads, AsHTON CHRON., Oct. 8, 1909, at 6 (describing rush of settlers to file for land opened in a portion of the Rosebud Reservation); Thousands File on the Rosebud: Many Wait All Night in Driving Rain to Register-Good Order in Crowds at All Filing Places, supra note 127 (reporting that tens of thousands of settlers were expected to have registered for Rosebud lands by the end of the registration process for that opening).

132. Less than One-Fourth File for Reservation Lands, AsHTON CHRON., July 22, 1910, at 6 (describing settler filings for surplus lands on the Cheyenne River Sioux and Standing Rock Reservations after the lottery determined individuals' priorities for filing). 
diminished. ${ }^{133}$ Somewhat ironically, then, the fact that the Rosebud had more commercially valuable land that more non-Indians wanted and eventually acquired meant, in the long run, that the Tribe would have no rights over that portion of its reservation at all. Put simply, the widespread on-the-ground violation of the Rosebud Tribe's rights was held to permit carte blanche violation of their rights of governance over that area in the future. ${ }^{134}$

Articles about the Rosebud allotment and openings run the gamut from extolling the fertility of the land, to describing the magnitude of the land rush, to describing the expulsion of the Sioux from the area ${ }^{135}$ Indeed, several convey, to varying degrees, a purposeful displacement of the Tribe from its lands. ${ }^{136}$ Perhaps the most explicit of these is a 1904 front-page article in Chicago Livestock World that reports that the allotted lands to which the Sioux were being confined after white settlement were "higher and drier" than the surplus lands that they were being forced to vacate. ${ }^{137}$ The article further explains that the Tribe was being effectively banished from its annual dance and celebration grounds, an area utilized by the Sioux "[s]ince a time whereof the memory of man runneth not to

133. Rosebud Sioux Tribe, 430 U.S. at 604-05 (relying on the fact that the area was ninety percent non-Indian in terms of population and land use at the time of the case to support its holding of diminishment); see also Solem v. Bartlett, 465 U.S. 463, 471 (1984) (citing Rosebud Sioux Tribe and another diminishment case to support the proposition that "[w]here non-Indian settlers flooded into the opened portion of a reservation and the area has long since lost its Indian character, we have acknowledged that de facto, if not de jure, diminishment may have occurred").

134. This is a familiar undercurrent in the Supreme Court's Indian law jurisprudence. In addition to diminishment cases like Rosebud Sioux Tribe, 430 U.S. at 604-05, it is evident in jurisdiction cases such as Oliphant v. Suquamish Indian Tribe, 435 U.S. 191, 193 \& n.1 (1978) (attributing the large number of non-Indian residents on the Suquamish reservation to alienation of individual Indian allotments), and City of Sherrill v. Oneida Indian Nation, 544 U.S. 197, 215-16 (2005). See also Royster, supra note 2, at 12 (discussing the injustice that was often attendant on an individual Indian's alienation of his or her allotment); Singer, supra note 75, at 606-07 (discussing the fact that New York bought the Oneida land at issue in City of Sherrill in violation of federal law). Note that the Suquamish reservation is similar to the Rosebud reservation in that it contains lands that non-Indians consider to be commercially valuable. See, e.g., Andrew P. Lawson, End of 50-year Lease Means Redemption for Suquamish, SeATTLE Times, May 3, 2007, http://seattletimes.nwsource.com/html/opinion/2003690 626_andrewlawson03.html (describing some of the reservation's commercially valuable, waterfront land).

135. See, e.g., An Iowan's View of Tripp County: Son of Lafe Young Writes of the Rosebud Country, Thinks Opening in October, supra note 131; The Rosebud Rush. Registry for the Allotment of South Dakota Land Is Commenced. Sioux Hold Final War Dance. Crowds Are Reported at All Points Selected for Registering, CHI. LIVESTOCK WORLD, July 5, 1904, at 1 [hereinafter CHI. LIVESTOCK WorLd, July 5, 1904]; Thousands File on the Rosebud: Many Wait All Night in Driving Rain to Register-Good Order in Crowds at All Filing Places., supra note 127.

136. CHI. LiVESTOCK WORLD, July 5, 1904, supra note 135; An Iowan's View of Tripp County: Son of Lafe Young Writes of the Rosebud Country, Thinks Opening in October, supra note 131; A New Town, S.D. ST. REV., May 29, 1908, at 4.

137. CHI. LIVESTOCK WORLD, July 5, 1904, supra note 135. 
the contrary." 138 The article also relates the comments of an Indian elder called Swift Bear, who "deliver[ed] a most bitter tirade against the whites for pushing the Indian into gradually smaller reservations, until, in the end . . . 'the Indian will have no country at all.",139 It continues by describing Swift Bear: "so great was the old man's influence among his followers that the Sioux finally refused to sell the lands at any price and the government was forced to pose as guardian of the Indians and to take possession of the reserve." $" 140$

A more musing account of Rosebud lands that were opened for settlement can be found in a 1908 article in a Nebraska newspaper - the Norfolk Weekly News-Journal. ${ }^{141}$ This article, which was written after one portion of the Rosebud Reservation was opened but before another portion was opened, was clearly geared toward attracting settlers to the soon-to-be-opened area. Accordingly, the article contains hardly any information about the Tribe itself. ${ }^{142}$ Nonetheless, the article is implicitly dismissive of tribal property rights and reflects a then-prevalent Lockean view $^{143}$ that the Tribe should be considered less deserving of its property because it was not utilizing the property according to English and American farming norms:

The opening of the Sioux Indian lands is developing them from that of the homes of indolent dependents of the government to the farm residences of thrifty Americans. The Indians who have been content to live lazily on the fertile soil and draw their liberal allowances will soon see more of their lands converted to useful purposes.

$\ldots$

One can drive over the range of Tripp county and see miles and miles of grazing lands and then return to the settled farm land of her sister

138. Id. In 1904, the Chicago Livestock World had a circulation of 12,785. N.W. AYER \& SON'S AMERICAN NEWSPAPER ANNUAL 148 pt. 1 (1904), available at http://cweb2.loc.gov/diglib/vols/ loc.gdc.sr.sn91012091.00143501991/pageturner.html?page $=150 \&$ size $=800$ (listing the newspaper as "Live Stock World" and noting its publication location as Chicago).

139. CHI. LIVESTOCK WORLD, July 5, 1904, supra note 135.

140. Id.

141. An Iowan's View of Tripp County: Son of Lafe Young Writes of the Rosebud Country, Thinks Opening in October, supra note 131.

142. Id.

143. The historian Herbert T. Hoover attributes this popular view to the work of an eighteenth century Swiss philosopher named Emer de Vattel, rather than to the earlier writings of John Locke. Hoover, supra note 9, at 73-74. 
county and hardly believe that three years ago Indian tepees were the only residences. Yet it is true. ${ }^{144}$

Finally, perhaps the least overt article I found that evidences approval of the Rosebud Sioux Tribe's dispossession is a 1908 article in the South Dakota State Review. ${ }^{145}$ It describes a new white town in the soon-to-be-opened portion called Winona. ${ }^{146}$ The writer expresses implicit approval of the fact that, although the town was started on an Indian allotment (which had presumably been alienated to a non-Indian), no Indians remain in the area:

The country around the new town-site . . . is rapidly becoming occupied with a first class citizenship right now, all of the Indian lands upon which patents have been issued having already been purchased by white farmers . . . and the allotments which cannot be patented have been leased to white men for a term of years. ${ }^{147}$

All three of these articles express, to varying degrees, a disregard for Indian property rights. The Chicago Livestock World piece puts somewhat of a rosy cast on the government's property grab, and it contains some inaccuracies (recall that the Rosebud Sioux had agreed to sell the lands at a fairly high price, but that agreement was never ratified). ${ }^{148}$ Nonetheless, the information would have been sufficient to put a non-Indian purchaser on notice of a probable violation of tribal property rights. It describes the Sioux leaving the more desirable, opened lands for "higher and drier" lands and notes that the Sioux were being required to vacate their annual dance and celebration grounds. One can infer from this information that the Sioux would not have easily given up such an area, especially to move to less desirable lands. Moreover, the information about Swift Bear's speech and the federal government's having been "forced" to take the Tribe's land would have directly put readers on notice of the possibility of unfair dealings and even outright theft.

The Norfolk Weekly News-Journal article provides much less information about the government's dealings with the Tribe but does evidence the writer's disregard for the tribe's property rights and at least his own satisfaction (and quite possibly the newspaper's) with the tribe's dispossession. Finally, the South Dakota State Review article suggests an

144. An Iowan's View of Tripp County: Son of Lafe Young Writes of the Rosebud Country, Thinks Opening in October, supra note 131.

145. A New Town, supra note 136.

146. Id.

147. Id.

148. HOXIE, supra note 2, at 156-57. 
attempt to create whites-only areas within the reservation. The writer's view appears to be that the more whites and the fewer Indians, the better, which is a particularly problematic outlook to hold on a reservationespecially given that some of the land at issue still belonged to Indian people and was merely being leased to the white possessors. Thus, even in the South Dakota State Review article, there is a sense that Indian dispossession is a favorable development, a view that necessarily implies a lack of respect for tribal property rights.

Finally, two other articles also bear on settlers' expectations in a different sense. Two very similar articles that appeared in South Dakota newspapers in April and May 1908 discuss a conflict between state authorities on the one hand and tribal authorities on the other regarding the authority of Indian police to make arrests in the opened area of the Rosebud Reservation. ${ }^{149}$ These articles show that the Indian police (which were then subject to considerable federal control ${ }^{150}$ ) did attempt to govern Indian allotments on the opened area of the reservation, a fact that is not acknowledged in the diminishment case, Rosebud Sioux Tribe v. Kneip. ${ }^{151}$ According to the articles, Indian police arrested a Sioux man named Chasing Crane on his allotment in the opened portion of the reservation for having permitted dancing there in violation of an order of the Indian agent. When he was released from his sentence of ten days labor, he notified county officers in the opened area, who then arrested the Indian police the next time they were found in the opened area. ${ }^{152}$ Given that Indian police were generally closely allied with the federal government at that time, this was a brazen act on the part of the county officers. The longer of the two articles notes that the question of the authority of Indian police to govern Indian allotments in the opened portion of the reservation "may have to be determined by the courts." ${ }^{\prime 53}$ But both articles seem to view the opened

149. Clash in Authority: Gregory County Peace Officers and Indian Police Force in Bull District in Serious Conflict, DaILY ARgus LeAder, Apr. 29, 1908, at 2 [hereinafter Clash in Authority]; In Conflict of Authority: Feud Started Between Indian Police and Gregory County Officials, POTTER COUNTY News, May 7, 1908, at 2 [hereinafter In Conflict of Authority].

150. See, e.g., Barbara Ann Atwood, Tribal Jurisprudence and Cultural Meanings of the Family, 79 NeB. L. ReV. 577, 588-89 (2000); cf. Indians Oppose Gamble Bill: Declare Tract To Be Opened Contains Minerals. Cheyenne River Council Protests Against the Partial Opening of the Reservation, and Will Send a Delegation to Washington to Present Views-Reservation Rules Adopted, DAILY PiONEER PRess, Jan. 29, 1908, at 9 [hereinafter Indians Oppose Gamble Bill] (reporting on the Cheyenne River Sioux Tribal Council's having adopted, in 1908, a "long list of rules . . . providing penalties for different offenses"- a fact which suggests that the content of tribal law remained largely under control of the tribal council at that time, and was not simply dictated by the federal government).

151. Rosebud Sioux Tribe v. Kneip, 430 U.S. 584, 603-04 (1977).

152. Clash in Authority, supra note 149.

153. Id. 
area as not part of the reservation because they refer to the Indian police as having "invaded Gregory county." "While the articles suggest that the opened area was not commonly viewed as part of the Rosebud Reservation, an attitude that accords with the Court's later rationale for holding the reservation diminished, they also evidence that there was considerable confusion about jurisdiction, at least in the early years - a fact that is not acknowledged in the Court's opinion on diminishment. Finally, while the irony of a tribal citizen seeking freedom from federal and tribal control by enlisting the help of state officials is noteworthy, it should be understood that county and state officials in South Dakota appear to have been more often the antagonists of tribal citizens rather than their protectors during the allotment era. ${ }^{155}$

\section{The Cheyenne River Sioux Reservation Opening}

On May 29, 1908, Congress approved the opening of the Cheyenne River Sioux Reservation, ${ }^{156}$ and President Roosevelt signed the bill three days later. ${ }^{157}$ By that time, an agreement with a tribe to open its reservation was seen as "superfluous." 158 Thus, although an attempt was made to discuss the federal proposal to open the reservation with the Cheyenne River Sioux Tribe, Congress proceeded despite the facts that (1) few tribal citizens had been able to participate in the discussion due to bad weather in March 1908 and (2) the Tribe's leader had asked that the Tribe have more time to consider the proposal. ${ }^{159}$ Additionally, those tribal citizens who were present for the discussion were told in no uncertain terms that Congress could and would proceed without their consent. ${ }^{160}$ Thus, even if they had consented, it would have been under coercion, as was the case with the 1890 opening. Finally, although many members of the Tribe later agreed to the originally proposed opening, the bill Congress passed created a much larger opening — a fact that rankled the Tribe. ${ }^{161}$

It appears that the opening of the reservation largely resulted from a settler grassroots effort. This is evident from the fact that the Indian agent for the Tribe suggested opening the reservation in fall of 1907, but the Indian Office in the Department of Interior responded that that office did

154. Id.; In Conflict of Authority, supra note 149.

155. See HoxIE, supra note 1, at 109, 117-18, 120 (describing the situation of Cheyenne River Sioux citizens vis à vis state and local officials (and under state law)).

156. Act of May 29, 1908, ch. 218, 35 Stat. 460.

157. HoxIE, supra note 1 , at 57.

158. Id. at 48 .

159. Id. at $51-57$.

160. Id. at 52-53.

161. See, e.g., id. app. 9. 
not "take the initiative"" in the opening of reservations. Rather, it was considered better policy to wait " [ [u]ntil there is some demand by the local community or the country at large." 162 By December 1907, such a movement was apparently building. A South Dakota Senator and a Congressman both introduced bills to open portions of the reservation that month. ${ }^{163}$ By January, in response to one of the bills, non-Indian residents of the former town of LeBeau, South Dakota, "passed resolutions requesting the extension of the provisions of the bill to include the whole of the [Cheyenne River Sioux and Standing Rock Sioux] reservations."164 Moreover, an editorial in the Daily Capital Journal the following spring portrayed an opening of the Cheyenne River Sioux and Standing Rock Reservations as a key to economic development of the region, opining that it would pave the way for " "the building of a great city right at Pierre.",165

The Cheyenne River Sioux Tribal Council objected to the opening almost immediately upon learning of the bills. ${ }^{166}$ And the council continued to object while the opening was being considered in Congress and after Congress had approved the opening. ${ }^{167}$ Importantly, at least some of the objections were reported in the popular press, as described below. None of these protests gained any traction with the federal government. ${ }^{168}$ Even more troubling, it appears that many tribal citizens did not learn of the opening at all until they literally saw white settlers arriving. ${ }^{169}$

While jurisdictional and other practices after the opening are of less relevance to the issue of justifiable expectations at the time of the opening, a few facts about life on the reservation after the opening are worth noting here. First, as mentioned above, the Cheyenne River Sioux opening attracted fewer settlers than previous openings had. As a result, much surplus land went unclaimed. But the best farming and grazing lands were

162. Id. at 49

163. Id. at $49-50$.

164. Open Every Acre of Reservations, supra note 91.

165. HoXIE, supra note 1, at 48, 62 n.7 (quoting PierRe DAILy CAPITAL J., Apr. 13, 1908, at 2). 166. Id. at 51 .

167. Id. at 57-58, 81-82 (noting that the council did at some point decide that it was amenable to the smaller opening that had been initially proposed); id. app. 9 (containing an April 25, 1908 letter from James Crow Feather, Chairman of the Cheyenne River Sioux Tribal Council, to Commissioner Leupp, explaining that Mr. McLaughlin had come to consult with the Tribe regarding the proposed opening of a portion of the reservation, that Mr. McLaughlin "left without learning the will of the majority of our people," and that subsequently the bill for the opening was dishonestly expanded to include a larger area of the reservation). Chairman Crow Feather's letter conveys a palpable sense of having been betrayed by the United States government, which elected to open the additional area of the reservation "against our will." Id. app. 9, at 3.

168. Id. at $57-58,81-82$.

169. Id. at $58-59$. 
sold off to non-Indians. ${ }^{170}$ The federal government viewed this unclaimed surplus land as tribal land and continued to exercise jurisdiction over it, as well as over Indians in both the ceded and unceded parts of the reservation. ${ }^{171}$ Moreover, tribal police, rather than South Dakota police, patrolled the entire Cheyenne River Sioux Reservation both prior to and after the opening. And Congress, at the behest of the state, specifically provided in 1903 that federal district courts would have jurisdiction over anyone who committed a major crime within any of South Dakota's reservations. ${ }^{172}$ Notably, South Dakota had enacted an earlier law attempting to cede all criminal jurisdiction to the United States for any violations of U.S. penal laws that occurred within reservations in the state. ${ }^{173}$ Additionally, federal officials in fact prosecuted non-Indians for crimes committed on the reservation such as stealing from tribal members, ${ }^{174}$ and the local superintendent of the reservation informally resolved disputes between Indians and non-Indians who lived near the reservation. ${ }^{175}$ Also, the tribal court was considered to be well functioning both prior to, and in the years after, the opening. ${ }^{176}$ These facts show that the opened portion of the Cheyenne River Sioux Reservation remained subject to considerable federal and tribal control after the opening, which should have alerted non-Indians who resided there that the opened portion of the reservation could continue to be subject to special jurisdictional schemes, including tribal jurisdiction.

Several of the news articles on the Cheyenne River Sioux opening do not address the question of tribal consent at all and simply report such things as the small number of settlers who filed for land or the progress of allotment. ${ }^{177}$ But a substantial number of articles address the issue of tribal consent to some degree, and although the information is sometimes conflicting, the articles evidence varying degrees of tribal dissatisfaction with the planned opening. The article I found that provides the most

170. Hoover, supra note 9 , at 88.

171. HOXIE, supra note 1 , at 90, 102-03.

172. Id. at 117, 120; see also Act of Feb. 2, 1903, ch. 351, 32 Stat. 793.

173. HoxIE, supra note 1, app. 97, at 3 (reproducing H.R. Rep. 2704).

174. Id. at 115; id. app. 93 (containing court documents from one such case involving thefts that occurred in 1914).

175. Id. at $123-24$.

176. Id. at $101-04$.

177. See, e.g., 1,800 Register for New Lands, supra note 127; Allotment Work Delayed: Survey to Decide Value of Coal Lands Near Thunder Butte, S.D., ASHTON CHRON., Nov. 13, 1908, at 3; Begin Lower Brule Allotments, POTTER COUNTY NEWS, July 30, 1908, at 2 (discussing both Cheyenne River Sioux and Lower Brule Sioux allotments); Less than One-Fourth File for Reservation Lands, supra note 132; There Are 1,000 Choice Land Claims on the Reservation: State Completes Selection of 32,000 Acres of Best Unallotted Lands. AsHTON CHRON., Dec. 3, 1909, at 6. 
in-depth coverage of the Tribe's objections is from a Twin Cities newspaper, which is significant given that a sizable percentage of settlers who sought lands on the Cheyenne River Sioux and Standing Rock Sioux Reservations appear to have come from Minnesota. ${ }^{178}$ This article describes the objections of the Cheyenne River Sioux Tribal Council as being tied to the facts that (1) the Tribe had not consented to the opening, and (2) the opening would affect valuable mineral lands, the value of which had not yet been determined. ${ }^{179}$ It further suggests that the council was concerned that the proposed opening would violate its treaties with the federal government. ${ }^{180}$ Significantly, the article also explains that the council resolved to write to the Indian Rights Association to enlist its help in opposing the bill to open the reservation. ${ }^{181}$

A 1908 South Dakota newspaper article portrays the Tribe's views as somewhat more malleable. It describes the Cheyenne River Sioux Tribe as objecting to the opening of a strip of land along the reservation's "northern line," but willing to agree to an opening provided certain requirements were met. ${ }^{182}$ The article closes with the information that the Tribe "selected a delegation to go to Washington to get their views incorporated as part of the act opening the reservation." 183

The Minnesota article is clear as to the Tribe's objections and was undoubtedly sufficient to alert readers to the Tribe's opposition to the opening - at least as of January 1908. While the latter article does not convey a wholesale rejection of the opening — or reflect that the Tribe had been told it had no choice but to consent - it does reveal that the Tribe had some specific objections to the opening. And one can infer that the Tribe objected to the opening absent incorporation of those terms.

An article from another South Dakota newspaper reports that the Tribe's delegation to Washington was successful in procuring many of the provisions sought, but that "about the only thing on which" the Tribe lost out was "the amount of land to be included in the strip through the center

178. See, e.g., 1,800 Register for New Lands, supra note 127 (reporting that three out of the ten first registrants for the land at Mobridge, South Dakota were Minnesotans and that the first two registrants for the lands at Pierre, South Dakota were Minnesotans).

179. Indians Oppose Gamble Bill, supra note 150.

180. Id.

181. Id.

182. Opening of Schnasse County. Cheyenne Indians Consent, but Want to Hold Northern Strip, Ashton Chron., May 1, 1908, at 3 [hereinafter Opening of Schnasse County]; see also HoxIE, supra note 1 , at 55 (describing a DAILY CAPITAL JOURNAL article that contains much of the same information).

183. Opening of Schnasse County, supra note 182. 
of the reservation." 184 While this third article suggests that the Tribe was able to obtain significant concessions, it importantly conveys that the Tribe continued to object to the taking of some of its lands.

Other articles are less definitive. For example, two very similar articles in a Nebraska and a South Dakota newspaper concerning the Cheyenne River Sioux and Standing Rock Sioux openings report that Indians generally benefit from the opening of their reservations because the selling off of surplus lands makes them richer. ${ }^{185}$ Despite this questionable claim, both articles also importantly convey that the Cheyenne River and Standing Rock surplus lands had been treaty-protected tribal property: "The lands that have been thrown open to settlement came into possession of the Indians through treaties with the government and were set apart for their sole use." " protected by treaty should have raised red flags about the propriety and legality of the government's taking of the land for settlers. Finally, the two articles acknowledge that hundreds of quarters of land will be leased to non-Indians by Indian owners. ${ }^{187}$ While the federal practice of leasing tribal and individual Indian lands during that era has rightly come under attack as unfair and abusive to Indian and tribal landowners, ${ }^{188}$ the possibility that non-Indians would be leasing tribal or individual Indians' lands suggests that the lessees might be under some degree of tribal control.

A much earlier article in the Minneapolis Tribune about the prospect of allotment (rather than a sale of surplus lands) on the Cheyenne River Sioux Reservation also provides somewhat mixed information. It interestingly (and perhaps fancifully) portrays conflicting opinions about allotment among Cheyenne River citizens as a struggle between the rich mixed-bloods and the poor full-bloods, with the poor favoring allotment and the rich opposing it. ${ }^{189}$ While the article portrays allotment as just, it would have put a non-Indian reader on notice of dissension among tribal citizens about the prospect of allotment — often a precursor to the selling off of surplus lands.

184. Indian Delegation to Washington Beats Gamble on Many Provisions of Cheyenne Bill, Daily ARgus LeAder, Apr. 20, 1908, at 1.

185. Indians Receive Choicest Lands on Reservation: Become Landlords by Leasing Their Lands to Ranchmen for Stock Ranges, ASHTON CHRON., Nov. 12, 1909, at 2 [hereinafter Indians Receive Choicest Lands]; Indians Get Best Lands: Sioux and Recently Opened Reservations Doomed to Extinction, NORFOLK WKLY. NeWS-J., Nov. 12, 1909, at 2 [hereinafter Indians Get Best Lands].

186. Indians Receive Choicest Lands, supra note 185; Indians Get Best Lands, supra note 185.

187. See sources cited supra note 186.

188. HoxIE, supra note 2, at 167-69; see also Hoover, supra note 9, at 71-72, 77-78.

189. South Dakota, 'The Rich Oppose the Poor,' MinN. TRIB., Mar. 13, 1900, at 3. 
An article in a South Dakota newspaper dated the day Congress opened the Cheyenne River Sioux Reservation provides implicit information about the injustice of the taking, though it describes nothing about the Tribe's reaction to it. ${ }^{190}$ The article describes the land retained by the Cheyenne River Sioux and Standing Rock Tribes as very small in comparison to the amount of land being taken for settlement, a contrast that alone should have put readers on notice of possible foul play. ${ }^{191}$ It also alludes to "[t]he country to be taken," which again suggests that the tribes are being acted upon by the government in this transaction, rather than having made a true bargain after negotiating at arm's length.

Finally, two South Dakota newspaper articles from December 1909 and April 1910 appear to describe a plan to eliminate the Cheyenne River Sioux Reservation that never came to fruition. ${ }^{192}$ The December article's subtitle states, "No Reservations in South Dakota 10 Years Hence If Present Movement Continues." 193 This article thus contemplates a complete end to reservations in South Dakota, but it importantly acknowledges that such a development is a possibility, not a certainty on which a non-Indian settler could depend. It goes on to report that a bill is currently under consideration for abolition of the Cheyenne River Sioux and Standing Rock Reservations. ${ }^{194}$ The article also notes that "the question of treaty consent of the Indians is no longer part of the process" of abolishing reservations. ${ }^{195}$ This information highlights the injustice that was often attendant on the taking of tribal land and the fact that treaty violation was also frequently involved.

The second article reports - again, apparently based on a federal plan that was subsequently abandoned - that the Cheyenne River and Standing Rock Tribes had "reluctantly" agreed to sell off the remainder of their reservations. ${ }^{196}$ The article goes on to note that "the protecting hand of the

190. Big Tract for Settlers. Only a Triangle of Reservations Left for Indians, ASHTON CHRON., May 29, 1908, at 3.

191. Id.

192. Indian Lands Are Disappearing from the Public Domain: No Reservations in South Dakota 10 Years Hence if Movement Continues, AshTON CHRON., Dec. 17, 1909, at 6 [hereinafter Indian Lands Are Disappearing from the Public Domain]; Indians Consent to the Opening of 10,000 More Farms: Must Learn by Coming in Contact With Whites-Ready Made House for Settlers, AshTon CHRON., Apr. 5, 1910, at 6 [Indians Consent to the Opening of 10,000 More Farms]. While further allotments to tribal members were made on the Cheyenne River Sioux Reservation after this time period, there is no indication that any further sales of surplus lands were made. Hoover, supra note 9, at $87-89$.

193. Indian Lands Are Disappearing from the Public Domain, supra note 192.

194. Id.

195. Id.

196. Indians Consent to the Opening of 10,000 More Farms, supra note 192. 
government will not be wholly withdrawn." 197 Information about the government's continuing role would have provided notice of the potential continued viability of the tribes: their members would not be immediately transformed into ordinary citizens but would retain their special status as tribal citizens. The information about the tribes' reluctance to let their lands go raises questions as to whether they had actually agreed to the cession. Finally, the article comments that, "from the standpoint of the state and of the public, there is every argument for breaking up reservations," which are described as "serious obstacles" to development of the western part of the state. ${ }^{198}$ This last comment evidences disrespect for tribal property rights and a facile willingness to sacrifice tribal rights for the cause of non-Indian interests. Again, these last two articles pertain to contemplated changes that never occurred. But the articles are nonetheless interesting in their ready acceptance of injustices against tribes. Moreover, even these articles contemplating drastic measures against the two tribes make no guarantees about their eventual disappearance.

\section{News About Other Tribes During the Allotment Period}

My searches for allotment-era news articles uncovered several articles about the allotment and opening of reservations outside of my immediate focus. These articles were also a mix of celebratory articles about the federal allotment policy ${ }^{199}$ and articles reflecting, to varying degrees, the injustice of the policy as implemented in individual cases. ${ }^{200}$ Notably,

197. Id.

198. Id.

199. See, e.g., Notes, supra note 90 (discussing the opening of the lands of the Spirit Lake Tribe, which was formerly called the Devil's Lake Tribe, in favorable terms); Want the White Father: The Crow Creek Reservation Indians Apparently Want to Sell Out., MinN. TRIB., May 27, 1888, at 8 (describing the Crow Creek Indians as favoring allotment); see also Kirkwood's Report, supra note 41 (advocating for allotment of Indian reservations generally).

200. See, e.g., Burke Is Reticent About Findings in Indian Fraud Probe: Intimates that Action to Be Recommended Will Be of Advantage to Indians, AsHTON CHRON., Sept. 9, 1910, at 2 [hereinafter Burke Is Reticent About Findings]; Indians Refuse to Leave Old Home: Chippewas of Mille Lacs Do Not Relish Idea of Moving to White Earth: Love Land of Forefathers: Troops May Be Required to Enforce Recent Change in Land Ownership, DAILY PIONEER PRESS, Sept. 2, 1910, at 1-2; Indians Want Money: Michigan Red Men Retain Lawyer to Recover Payment for Lands, DAILY PIONEER PRESS, Sept. 10, 1910, at 3; Indian's War Shirt Is Too Small for Taft, ASHTON CHRON., Feb. 25, 1910, at 7; Received as an Act of Courtesy: Protesting Indians Visit Secretary of the Interior Hitchcock, MinN. TRIB., June 16, 1901, at 2 [hereinafter Received as an Act of Courtesy]; Save Lands for Indians: Government to Act Promptly on White Earth Reservation Deals. Many Sales Held Illegal; Only Mixed Bloods Can Legally Dispose of Their Land Holdings, DAILY PIONEER PRESS, Dec. 2, 1909, at 1-2 [hereinafter Save Lands for Indians]; The Crow Creek Reservation, WINONA DAILY REPUBLICAN, Apr. 4, 1885, at 4; Will Try to Save Land for Indians: Federal Government to Make Fight for Five Civilized Tribes, AshTON CHRON., Oct. 8, 1909, at 6 [hereinafter Will Try to Save Land for Indians]; see also Census Counting Makes Noble Red Take to Warpath: New Mexico Militia Ordered Post 
a significant number of articles do directly demonstrate the injustices wrought by the policy, ${ }^{201}$ and several others reveal such injustices albeit in either implicit or equivocal terms. ${ }^{202}$ For instance, four articles discussed problems, including unlawful transfers and other injustices, that occurred during the implementation of the allotment policy, which, in three of the cases, threw the validity of the transferees' titles into serious question. ${ }^{203}$ One of the examples involves the Crow Creek Reservation in South Dakota. The Crow Creek Sioux Tribe is a constituent tribe of the Great Sioux Nation, although its reservation is also home to Sioux who were removed from Minnesota. ${ }^{204}$ An 1885 news article describes an attorney general opinion stating that an earlier opening of that reservation by presidential proclamation was invalid because the land was protected by treaty. ${ }^{205}$ The article concludes that "[ $t$ ]he land has already been covered with entries by the white settlers . . , but it is probable that the effect of this decision will

Haste to Scene of the Alleged Indian Outbreak, Ashton Chron., May 20, 1910, at 7 (reporting "general dissatisfaction with the whites [among the Taos Pueblo] because of what the Indians regard as encroachments on their rights"). Note that, although Pueblo lands were never allotted or opened to non-Indian settlement by the federal government, non-Indians still settled lands belonging to the Pueblo tribes without authorization, and the federal government eventually granted some non-Indian settlers title to the lands they had settled, comprising over 41,000 acres in total. See Richard W. Hughes, Indian Law, 18 N.M. L. REV. 403, $463-64$ (1988); John W. Ragsdale, Jr., Law and Environment in Modern America and Among the Hopi Indians: A Comparison of Values, 10 HARV. ENVTL. L. REV. 417, 451 n.138 (1986).

201. See supra note 200 and sources cited therein.

202. Kirkwood's Report, supra note 41 (noting that tribal land titles "are not such as the courts are bound to protect" and stating that the reservations have generally been "set apart by treaty, or law, or executive order"); Mr. Donnelly on the Sioux Reservation Sale, WinONa Daily REPUBLICAN, July 7, 1868, at 2 (noting that the Sioux Reservation in Minnesota "belonged to the Indians, by solemn treaty," and that "[t]he Government took the [r]eservation, in order to make room for white settlers," but that it obligated itself to sell the reservation and invest the funds for the benefit of the friendly Sioux); Mr. Schurz's Experiment, MINN. TRIB., Mar. 18, 1880, at 2 (favorably describing the allotment and opening of the Ute Tribe's "magnificent reservation to white settlement"); Notes, supra note 90 (noting that "[t]he Indians are not getting any of the worst of [the land market], even if their lands are being given away to the white man"); Otis' Days Numbered, supra note 91 (discussing the fact that settlers were building on lands within the Leech Lake Reservation prior to its being "offered for sale," despite a contrary order of the Secretary of the Interior and also noting that "[i]t is not expected that the [Interior] department will take any action to eject these parties").

203. Burke Is Reticent About Findings, supra note 200; Save Lands for Indians, supra note 200; The Crow Creek Reservation, supra note 200; Will Try to Save Land for Indians, supra note 200. A fifth article describes the efforts of the Crow Tribe of Montana to protest the opening of its reservation. Indian's War Shirt Is Too Small for Taft, supra note 200. At a minimum, this article would have put non-Indians on notice of the Tribe's objections to the opening of its reservation.

204. Frank Pommersheim, Representing Native People and Indian Tribes: A Response to Professor Allegretti, 66 FORDHAM L. REV. 1181, 1183 n.7 (1998); Charles F. Williams \& Rachel T. Van Heel, Lincoln's Other War: The Dakota Sioux Uprising \& Trials of 1862, INSIGHTS ON L. \& SOC'Y, Winter 2009, at 24, 30; History of the Reservation, DiAmOND Willow MinisTRIES, http://www.d-w-m.org/pages.asp?pageid=66982\#noref[2/20/2012 (last visited June 27, 2012).

205. The Crow Creek Reservation, supra note 200. 
be to deprive them of any rights they may have acquired."206 Putting aside the one-sided cast of this reporting, which incites the reader's sympathy for the settlers but makes no attempt to foster sympathy for the injustices experienced by the Sioux residing at Crow Creek, the article would certainly have put readers on notice that non-Indian title to lands on reservations may not be secure in all cases, or-at the very least - that special rules may govern such title.

Similarly, a 1909 Pioneer Press article described a planned lawsuit by the federal government against non-Indian buyers of allotments and their conveyees on the White Earth Reservation in Minnesota to enjoin the cutting of timber and other actions on the land. ${ }^{207}$ The article avers that timber lands worth a whopping \$5 million are to be restored to their rightful full-blood Indian owners and reports that a "prominent government official" has promised that "under no circumstances will the cases be compromised." 208

A third article, from a South Dakota paper, describes the government's litigation to vindicate the rights of Indian allottees from the Five Civilized Tribes against "those persons who, by various means" obtained allotments from tribal citizens even though those allotments could not legally be alienated. ${ }^{209}$

A final article on problems and injustices resulting from the implementation of the allotment policy is more indirect but has widespread significance. A 1910 article in a South Dakota paper describes a federal investigation into "the alleged graft in Indian lands" under the allotment policy and reports that "the accusations filed have just grounds," "startling facts have been unearthed," and the actions taken in response to the investigation "will be beneficial in no small way to the Indians." 210

All four of these articles should have suggested to any readers that were considering settling Indian lands or who were in the process of doing so that Indians or tribes may have continuing rights to such lands in some circumstances. The fourth article also importantly describes how widespread the problem was and would have put readers on notice of likely

206. Id; see also Squatters Have to Go, DAILY ARGUS LEADER, May 24, 1889, at 3 (describing the Indian Commissioner's order to remove squatters from the Crow Creek and Lower Brule reservations as "senseless"); $c f$. Agreement with the Sioux, supra note 115, § 23 (retroactively allowing these settlers a chance to perfect their land claims). Note that the page number for the Daily Argus Leader article cited here is uncertain because the microfilm appeared to have been scanned out of order.

207. Save Lands for Indians, supra note 200.

208. Id.

209. Will Try to Save Land for Indians, supra note 200.

210. Burke Is Reticent About Findings, supra note 200. 
ameliorative actions by the federal government. And, in cases where the federal government opposed tribal interests, the tribes' claims of injustice were directly stated in at least some cases. ${ }^{211}$

The newspaper articles described above provide a sense of what information average non-Indian citizens were likely to have had regarding allotment and the selling off of surplus tribal lands to non-Indians, particularly with respect to violations of tribal property rights. Collectively, the articles tell us that non-Indians had imperfect and sometimes conflicting information about the allotment and opening of individual reservations and, specifically, the fact that lands were being taken from tribes (and individual Indians) often without their consent and in derogation of tribal and individual property rights. In many cases, the information available in newspapers did provide evidence of injustice to tribes and individual Indians in the taking of their property. Moreover, historical evidence suggests that settlers were frequently instrumental in convincing the federal government to open reservations to non-Indian settlement. ${ }^{212}$ In those instances, which included the opening of the Cheyenne River Sioux Reservation, such settlers were clearly complicit in any resulting deprivation of tribal property rights.

\section{The Meaning of "Justifiable Expectations"}

To fully evaluate whether settlers who purchased surplus lands on reservations had justifiable expectations that the reservations and tribes would disappear - thereby eliminating any possibility of tribal jurisdiction-we first need to settle on a definition of "justifiable expectations." The concept of justifiable expectations is often alluded to in Supreme

211. See, e.g., Received as an Act of Courtesy, supra note 200 (describing a meeting between members of the Kiowa, Comanche, and Apache tribes and the Secretary of the Interior during which several of the tribal members "declared that the agreement for the cession of their lands had not been secured by legitimate methods").

212. See, e.g., HoXIE, supra note 1, at 47-49 (describing the public sentiment among the people of South Dakota, and so-called "boosters" in particular, that the large reservations in the state should be opened to settlement to make room for non-Indian economic development and quoting the Indian Office's statement that it did not recommend the opening of reservations absent "some demand by the local community or the country at large"); Hoover, supra note 9, at 63 (describing the demands of a group of territorial residents who met in Deadwood, South Dakota, in May 1882 and urged that "“[s]ecuring the opening of the Sioux Reservation to actual settlers, at the earliest possible time,' . . . would be most beneficial to people in their quest for statehood" and noting that their statement was "[t]ypical" during that time period); Open Every Acre of Reservations, supra note 91; see also Kirkwood's Report, supra note 41 ("Our people in their march westward have surrounded these reservations, and seeing in them large tracts of fertile land withheld from the purpose for which they believe it was intended-cultivation-have called upon the executive and legislative departments to make new treaties, new laws, and new orders, and these calls have generally been heeded."). 
Court opinions, but it is seldom defined. ${ }^{213}$ And even scholars examining the concept in other contexts have not tended to undertake stringent analyses of the meaning of the term. ${ }^{214}$ Thus, I will use other sources to elucidate the concept. Specifically, I will examine dictionary definitions and policy concerns, and then I will proceed to examine a philosophical definition of "justice" rooted in the work of Jürgen Habermas, as well as several approaches to justifiable expectations that are based on legal doctrine. The doctrine-based approaches include the following: (1) allotment-era laws bearing on tribal jurisdiction; (2) an adaptation of the equitable defense of unclean hands; (3) use by analogy of the international law of state succession; and (4) use by analogy of the concept of inquiry notice as applied in real covenants and equitable servitudes law.

\section{Dictionary Definitions and Policy Concerns That Support Their Application}

The definition of "expectation" is fairly straightforward. The dictionary definitions that appear most relevant include "anticipation," "something that is expected," and "the basis for expecting something." 215 Dictionary meanings of "justifiable" suggest that reasonableness is important and further add a moral concept of justice. For instance, the first entry in the dictionary definition of "justify" is "to prove or show to be just, right, or reasonable," and the dictionary definition of "justifiable" is "defensible" or "excusable." 216 Moreover, "justify" has the same root as the word "just," a fact that reinforces the idea that "justifiable" has a moral

213. Justice Blackmun's suggestion, in a case addressing a due process challenge to revocation of a nursing home's authority to provide government-funded services, that the Court's understanding of " justifiable" expectations" should be informed by "[r]eason and shared perceptions" appears to be one of the few attempts to define the term at the Supreme Court level. See O'Bannon v. Town Court Nursing Ctr., 447 U.S. 773, 797 (1980) (Blackmun, J., concurring in the judgment); see also Amanda Yellon, The Fourth Amendment's New Frontier: Judicial Reasoning Applying the Fourth Amendment to Electronic Communications, 4 J. BUS. \& TECH. L. 411, 417 (2009) (interpreting Justice Harlan's concurrence in Katz v. United States, 389 U.S. 347, 360 (1967) (Harlan, J., concurring), as creating a test for justifiable expectations).

214. Some of the few instances in legal scholarship where the meaning of "justifiable expectations" is analyzed in some measure include: Kristin M. Barone, Through the Looking Glass of the Fourth Amendment: The Unintended Consequences of Search Reform Leads to a Technological Erosion of Security in the Home, 13 LOY. J. PUB. INT. L. 159, 177 n.110 (2011) (suggesting that one must have a right to an expectation for it to be considered justifiable); Daniel P. O'Gorman, Looking Out for Your Employees: Employers' Surreptitious Physical Surveillance of Employees and the Tort of Invasion of Privacy, 85 NEB. L. REV. 212, 245 (2006) (same); Yellon, supra note 213, at 417 (interpreting Justice Harlan's concurrence in Katz v. United States, 389 U.S. 347, 360 (1967) (Harlan, J., concurring), as creating a test for justifiable expectations).

215. WEBSTER'S THIRD NEW INTERNATIONAL DICTIONARY, UNABRIDGED (2002),

http://unabridged.merriam-webster.com.

216. Id. 
component; indeed, definitions of "just" include "conforming to some standard of correctness" and "acting or being in conformity with what is morally right or good." 217 From these definitions and the word's etymology, we can glean that the term "justifiable" denotes reasonableness and that it is also logically tied to justice. In other words, expectations of continued injustice, even if empirically reasonable, should not be viewed as justifiable. ${ }^{218}$ The definitions quoted above tell us that "expectation" has a subjective component - in other words, the state of mind of a person with expectations is necessarily that of someone anticipating or expecting something - whereas "justifiable" is an objective standard that includes reasonableness and justice. ${ }^{219}$

The understanding of "justifiable" as being tied to justice is also supported by important policy considerations. For one, it seems unfair and anomalous to hold that one group had justifiable expectations that the government would continue to thwart the property rights of another group. While the Court appears to decide Indian law cases at least partially on this very basis, such reasoning gives one group the right to impose government-sanctioned harm on another group because the harmed group was historically subject to such harm. As a nation, we have definitively rejected this approach when applied to African-Americans, ${ }^{220}$ and it is now well-settled that this line of reasoning generally conflicts with important constitutional values such as equal protection. ${ }^{221}$ In the context of federal Indian law, such reasoning syllogistically and unfairly allows past injustice to serve as a basis for present injustice, thus resulting in extreme and ever increasing under-protection of tribal sovereign rights. Finally, some commentators who have examined the concept of justifiable expectations

217. Id. While under another dictionary definition, "just" simply denotes reasonableness, see id., when it is said in a legal context that something is just, the designation tends to denote a more lofty quality than mere reasonableness. See, e.g., BlaCK's LAW DictionARY (9th ed. 2009) (defining "just" as "[1] egally right; lawful; equitable"); see also Barone, supra note 214, at 177 n.110 (suggesting that one must have a right to an expectation for it to be considered justifiable); O'Gorman, supra note 214 , at 245 (same).

218. Cf. Craig v. Boren, 429 U.S. 190, 201-02 \& nn.13-14 (1976) (rejecting reliance on gender-based stereotypes to support a law treating men and women differently despite the fact that the stereotypes enjoyed some empirical support).

219. Cf. Royster, supra note 56, at 643-44 (addressing only the subjective aspect of justifiable expectations)

220. See generally Shelley v. Kraemer, 334 U.S. 1 (1948).

221. Cf. Lawrence v. Texas, 539 U.S. 558, 584 (2003) (O'Connor, J., concurring in the judgment) ("A legislative classification that threatens the creation of an underclass ... cannot be reconciled with the Equal Protection Clause." (alteration in original) (internal quotation marks omitted)); Romer v. Evans, 517 U.S. 620, 635 (1996) ("A State cannot so deem a class of persons a stranger to its laws."). Continuing to enforce the GAA in this way also likely violates the International Covenant on Civil and Political Rights. See COHEN's HANDBOOK, supra note 4, § 5.07[2][c] \& n.518. 
in other contexts have implicitly included a requirement of justice in their definitions. ${ }^{222}$

As further explained below, these definitions and policy considerations provide some assistance in determining whether the expectations of non-Indian purchasers of surplus lands during allotment concerning the possibility of tribal jurisdiction were justifiable. Although the newspaper articles discussed above contained some inaccuracies and certainly did not provide complete information as to the injustices inherent in specific tribal land cessions and the opening of reservations to settlement, they demonstrate, collectively and often individually, that the settlers who bought tribal lands on reservations should not be understood to have had justifiable expectations that the tribes would disappear, thus eliminating the possibility of tribal jurisdiction.

\section{a. Expectations}

The first question is whether the news articles created expectations that the reservations and tribal governments would disappear, thus eliminating any possibility of tribal jurisdiction. In general, the articles cannot be read to support a federal guarantee or promise as to the disappearance of reservations such as would be entitled to the weight of an expectation. Some articles expressed a hope that such a contingency would occur, ${ }^{223}$ and two South Dakota newspaper articles voiced a probability that reservations in South Dakota would disappear within ten years if a pending bill passed. ${ }^{224}$ While the latter of these two articles did state that the Cheyenne Sioux had agreed to sell off the remainder of their reservation lands, ${ }^{225}$ - a statement that may well have been interpreted to foretell the demise of that reservation - that plan was abandoned, and no lands were sold under that pretense. The same article also noted that the government would remain in a protective posture toward tribal citizens, ${ }^{226}$ a relationship that could well entail special jurisdictional rules that could affect non-Indians in the vicinity of Indian landowners. Somewhat similarly, the articles about the clash of authority on the opened portion of the Rosebud Reservation can be read to suggest a diminishment of that reservation, ${ }^{227}$ although one of them directly reports legal ambiguity as to that proposi-

222. See, e.g., O'Gorman, supra note 214, at 245.

223. See, e.g., Kirkwood's Report, supra note 41; The Sioux Reservation Bill, supra note 120.

224. Indian Lands Are Disappearing from the Public Domain, supra note 192; Indians Consent to the Opening of 10,000 More Farms, supra note 192.

225. Indians Consent to the Opening of 10,000 More Farms, supra note 192.

226. Id.

227. Clash in Authority, supra note 149; In Conflict of Authority, supra note 149. 
tion, ${ }^{228}$ and the content of both articles shows that the matter was not beyond dispute.

In short, although many of the articles do suggest that forcible assimilation of the Indians was the ultimate goal of the allotment policy, and abolition of reservations was implicit in this goal, very few of the articles can be read to support an anticipation of the abolition of any particular reservation. The only possible exceptions would be those about the clashes of authority on the Rosebud Reservation and those about the plans to abolish the Cheyenne River Sioux and Standing Rock Sioux Reservations, but, in the latter reservations, those plans of abolishment were subsequently abandoned before any meaningful reliance could have occurred. Moreover, both of the Rosebud articles demonstrate some degree of legal uncertainty, and one of them directly reports such ambiguity.

\section{b. Justifiability}

Even assuming that such expectations existed, either in the case of the Rosebud Sioux Reservation or more broadly, were they justifiable? Under the dictionary definitions quoted above, justifiability has two major components: reasonableness and justice. Examining reasonableness first, the question of reasonableness overlaps with the question of whether expectations existed at all. Arguably, the ultimate success of the allotment policy was too uncertain to give rise to a reasonable anticipation of the abolition of reservations and the dismantlement of tribal governments. To be sure, such a goal appears to have been a widely held aspiration among non-Indians, yet assimilation was unquestionably an ongoing, somewhat gradual process, as reflected in the initial requirement under the GAA, that individual Indians were to hold allotments in trust for twenty-five years and in the news articles reporting on the progress of assimilation. ${ }^{229}$ Moreover, the popular press reported some of the numerous failings of the policy, and those articles underscored federal support for wronged tribal citizens. ${ }^{230}$ Given that the abolition of reservations and the dismantlement of tribal governments were very much still in process during the allotment era and that there were serious, recognized problems in the pursuit and implementation of those goals, it is questionable whether non-Indian settlers could have reasonably relied on their ultimate achievement.

228. Clash in Authority, supra note 149.

229. See, e.g., Royster, supra note 2, at 10; The Bear Dance, S.D. ST. REV., May 29, 1908, at 3 (contrasting the hardworking Cheyenne River Sioux Indians with the Indians on the Ute Reservation and arguing for assimilationist training on that basis).

230. Burke Is Reticent About Findings, supra note 200; Save Lands for Indians, supra note 200; The Crow Creek Reservation, supra note 200; Will Try to Save Land for Indians, supra note 200. 
A thornier problem for the non-Indian settlers, however, is whether their expectations, assuming they existed and were reasonable, were grounded in justice. In fact, as shown above, non-Indian newspaper readers were on notice in many cases of the fact that the tribes objected to the federal taking of their lands. Several articles discussed the treaty-protected character of such lands. And some articles acknowledged the use of federal coercion and other unconscionable tactics to appropriate tribal lands. Even more problematic are the many cases, such as that of the Cheyenne River Sioux, in which the reservations were opened to non-Indian settlement at least partly as a result of the insistence of non-Indians living in the area. In numerous articles, a tone of disrespect or even scorn for tribal property rights is evident, which appears to have largely reflected popular sentiment ${ }^{231}$ and which similarly evidences a level of complicity.

While the Supreme Court in Lone Wolf sanctioned the federal government's ability to unilaterally abrogate tribal rights in 1903, even that opinion did not pretend that the course it sanctioned was a just one. Instead, the Court merely deemed the issue a nonjusticiable political question. ${ }^{232}$ The injustice of the opinion would have been evident to anyone who understood tribes and Indians to have anything approaching the same rights as others. Indeed, it was subject to strident criticism based on its injustice from a contemporary senator who commented that Lone Wolf was " Dred Scott decision No.2, except that in this case the victim is red instead of black. It practically inculcates the doctrine that the red man has no rights which the white man is bound to respect . . ." ${ }^{233}$ Forming an expectation of freedom from tribal jurisdiction based on anticipation of the federal government's continuing, unremedied violation of tribal rights simply cannot be viewed as just under an ordinary meaning of the word. Even if the unenlightened sentiments of the allotment era obscured the injustice for many people of that era, it is the quality of injustice rather than its historical perceptibility that is most relevant for our purposes.

231. See supra note 32 and sources cited therein.

232. Lone Wolf v. Hitchcock, 187 U.S. 553, 567-68 (1903). The portion of the Lone Wolf holding that federal action toward tribes is a nonjusticiable political question is no longer good law, COHEN'S HANDBOOK, supra note 4, $\$ 5.04[2][\mathrm{a}]$, although the federal government retains the power to unilaterally abrogate treaties with tribes, provided it makes its intent to do so sufficiently clear. $I d$. $\S \S$ 2.02[1], 5.01. Just compensation would be required for the taking of property rights in such a case if a Fifth Amendment violation could be shown. See generally United States v. Sioux Nation of Indians, 448 U.S. 371 (1980).

233. Bethany R. Berger, Red: Racism \& The American Indian, 56 UCLA L. REV. 591, 630 (2009) (citing DAVID E. WILKINS, AMERICAN INDIAN SOVEREIGNTY AND THE U.S. SUPREME COURT: THE MASKING OF JUSTICE 116 (1997)). 
Because the Supreme Court is giving weight to these settlers' presumed justifiable expectations in current controversies, it is fair to evaluate their justifiability under current standards of justice.

\section{A Habermasian Notion of Justice}

In his essay, "Struggles for Recognition in the Democratic Constitutional State," Jürgen Habermas advances several ideas that are useful in developing a deeper understanding of justice in a multicultural society, particularly in one that includes distinct and cohesive tribal cultures that claim their own rights to sovereign governance. ${ }^{234}$ He explains, relying on the work of Amy Gutmann, that there are two core components to equal respect for all citizens: "(1) respect for the unique identities of each individual . . . and (2) respect for those activities, practices, and ways of viewing the world that are particularly valued by, or associated with, members of disadvantaged groups." 235 He further explains that the goal of this second demand for respect is primarily to "protect[] the integrity of the traditions and forms of life in which members of groups that have been discriminated against can recognize themselves" and that "the failure of cultural recognition is connected with gross social discrimination, and the two reinforce each other." rights requires a politics of recognition that protects the integrity of the individual in the life contexts in which his or her identity is formed."237 Finally, he notes that "the theory of rights" forbids citizens in a democratic constitutional state from "privileg[ing] one form of life at the expense of others within the nation." 238

The goal of the allotment policy, as described above, was to destroy rather than to respect tribal culture. Indeed, politicians of the time made no bones about their intent to "kill the Indian . . . and save the man." "239 A central component of this plan was to alienate, forcibly if necessary, tribal property, so that Indians would have to learn to farm and to hold property individually rather than utilize the system of common ownership that accorded with their cultural traditions. Far from protecting the life contexts in which an individual tribal citizen's identity was formed, the federal government sought to destroy those life contexts.

234. JÜrgen Habermas, The Inclusion of the Other: Studies in Political Theory 203-36 (Ciaran Cronin \& Pablo De Greiff eds., 1998).

235. Id. at 205 (quoting Amy Gutmann). While Habermas discusses the views of Charles Taylor in this section of the essay, my quotes include only statements he affirmatively espouses as his own.

236. Id. at $205-06$.

237. Id. at 208.

238. Id. at 220.

239. Rolnick, supra note 3, at 980 (internal quotation marks omitted). 
Under Habermas's view, then, the allotment policy was unjust because it was designed to destroy tribal culture, and the takings of tribal property effected to implement that policy were part of that injustice. Indeed, it cannot seriously be questioned that the allotment policy did exactly what is forbidden under a Habermasian view: it privileged Western, individualized notions of property over the collective ownership favored by Native cultures with the goal of destroying those very cultures. ${ }^{240}$ Furthermore, Habermas's prescription of respect for minority groups arguably applies with even more force in the context of federal Indian law, where the federal government has undertaken unique obligations toward tribes through treaties and other agreements as well as through its course of conduct, both historically and in the present.

In addition to the insights about the allotment policy that can be gleaned from Habermas's discussion of each nation's duty to allow minority ways of life to continue, his explanation of individual rights sheds further light on the injustices inherent in the allotment policy. He writes that "[a] legal order is legitimate when it safeguards the autonomy of all citizens to an equal degree. The citizens are autonomous only if the addressees of the law can also see themselves as its authors." ${ }^{241}$ The takings of tribal lands described above that the federal government effected either without tribal consent or with coerced consent did not safeguard the autonomy of tribal members to the same extent that non-Indian autonomy was safeguarded. Property rights of whites, particularly white men, have traditionally been respected in the United States, but the allotment era demonstrates that this has not been true for tribes and Indians. ${ }^{242}$ Furthermore, it is hard to imagine that the tribal citizens targeted by the allotment policy could have seen themselves as potential authors of the laws implementing the policy (or probably any other federal laws of the period) or even that they would have viewed themselves as having federally recognized autonomy. ${ }^{243}$ In short, tribal citizens were not accorded the

\footnotetext{
240. See supra Part II, and supra note 3 and accompanying text (discussing the purpose of the allotment policy).

241. HABERMAS, supra note 234, at 215 (emphasis removed).

242. Tribal property rights have been violated in other contexts as well. See, e.g., Tee-Hit-Ton Indians v. United States, 348 U.S. 272 (1955).

243. See, e.g., HOXIE, supra note 1, app. 9 (containing an April 25, 1908 letter from James Crow Feather, Chairman of the Cheyenne River Sioux Tribal Council, to Commissioner Leupp in which Chairman Crow Feather expresses a sense of voicelessness with respect to federal policy and of betrayal by the federal government); $i d$. app. 81, at 6-7 (reproducing the Superintendent of the Cheyenne River Sioux Reservation's March 1912 statement that he "exercise[s] almost complete control over the Indians who are wards of the Government" and that "this control includes their freedom in moving about or leaving the reservation, the use of their property, . . . and their perfect subjection to orders issued by the Agent").
} 
autonomy of white citizens under the allotment policy, and this fact points squarely to its injustice under a Habermasian view. The injustice of the allotment policy means that those non-Indian settlers who benefitted from it and knew that tribal land was being taken by coercive means or without true tribal consent cannot have formed justifiable expectations based on the idea that the policy would be fully implemented at some point in the future.

Some may argue that it is anachronistic and consequently unfair to apply a Habermasian notion of justice to both settlers' states of mind and their actions during the allotment era. It is true that the allotment era predates Habermas, and the idea of protecting minority cultures was by no means prevalent during the allotment era. I do not view these facts as problematic, however, because my purpose is not to judge the non-Indian purchasers of tribal lands, but rather to determine whether their presumed expectations as to the eventual disappearance of Indian tribes should be given weight in current controversies about tribal jurisdiction. Because current tribal governance rights are at issue, there is nothing anachronistic about applying current notions of justice, even if historical expectations are part of this analysis, as the Supreme Court has made them. Whatever our nation's previous failings, it is simply poor policy to continue to enforce in courts of law historical expectations that are rooted in what we now can readily recognize as injustice.

\section{Cases and Statutes Pertaining to On-Reservation Jurisdiction}

\section{a. Relevant Statutes}

During the allotment era, several laws gave the federal government jurisdiction over some types of crime on the reservation, such as crimes between non-Indians and Indians and major crimes by Indians. ${ }^{244}$ A separate and somewhat repetitive federal law, enacted at the urging of South Dakota in 1903, provided that the federal government would have jurisdiction over any person who committed an enumerated major crime on a South Dakota reservation, ${ }^{245}$ and South Dakota had previously passed a similar but broader memorial. ${ }^{246}$ Such laws provided notice to the general

244. COHEN'S HANDBOOK, supra note 4, $\S 1.03[4][\mathrm{b}]$ \& $\mathrm{n} .342$ (discussing the history of the Indian Country Crimes Act, now codified at 18 U.S.C. $\S 1152$ ); id. $\S 1.04$ (discussing the history of the Major Crimes Act, now codified at 18 U.S.C. $\$ 1153)$.

245. HoxIE, supra note 1, at 117, 120; see also Act of Feb. 2, 1903, ch. 351, 32 Stat. 793. The law was not completely repetitive of the federal statutes discussed above because the Supreme Court had previously held states to have jurisdiction over non-Indian-on-non-Indian crimes committed on reservations. United States v. McBratney, 104 U.S. 621,624 (1881).

246. HoXIE, supra note 1, app. 97, at 3 (reproducing H.R. Rep. 2704). 
populace that reservations were places where special jurisdictional rules applied. Reservations were not merely islands of Indian settlement within states; in an important sense, they were not part of states at all. ${ }^{247}$ These laws made no distinction between open and closed reservations and would have put non-Indian settlers on notice that they were buying land in an unusual place where special rules applied. While the statutes did not speak directly to the possibility of tribal jurisdiction, they nonetheless provided notice of the special character of reservation lands. Significantly, in South Dakota, the absence of state interest on reservations was even more acute than it was elsewhere in the country at that time: South Dakota had apparently attempted to cede its right to try non-Indians who committed crimes against other non-Indians on reservations to the federal government. $^{248}$

These statutes, by providing for special jurisdictional schemes on reservations and by making no distinction between open and closed reservations, should have put prospective non-Indian purchasers on notice of the possibility that any lands they purchased on a reservation may be subject to different jurisdictional rules than lands that had not been taken from an Indian tribe.

\section{b. Case Law}

While the allotment-era case law is collectively somewhat ambiguous, some of the cases pertaining to jurisdiction on reservations provided direct notice of the possibility that non-Indians could be subject to tribal jurisdiction. For instance, a very early Supreme Court case, Johnson $v$. M'Intosh ${ }^{249}$ suggested that non-Indians who bought land from tribes would hold that land subject to tribal law and custom. ${ }^{250}$ While not directly applicable to the context of purchases of surplus lands during the allotment era, during which non-Indians bought tribal lands from the federal government, Johnson importantly recognizes the possibility of non-Indians being subject to tribal jurisdiction. A few years later, in Worcester v. Georgia, ${ }^{251}$ the Court definitively described tribal jurisdiction as exclusive within the boundaries of a reservation. ${ }^{252}$

247. See United States v. Kagama, 118 U.S. 375, 384 (1886) (stating that tribes "owe no allegiance to the states, and receive from them no protection").

248. See supra note 245 and sources cited therein.

249. 21 U.S. (8 Wheat.) 543 (1823).

250. Id. at 593; Tweedy, supra note 5 , at 666 .

251. 31 U.S. (6 Pet.) 515 (1832).

252. Id. at 557; Tweedy, supra note 5, at $672 \&$ n.95. 
Although these early cases did not specifically address the question of how non-Indian land ownership within a reservation affects the reach of tribal jurisdiction, two opinions issued by the Supreme Court and the Court of Appeals for the Eighth Circuit, in 1904 and 1905 respectively, prior to the opening of the Cheyenne River Sioux Reservation, address that very question and uphold tribal jurisdiction over non-Indians on fee lands. ${ }^{253}$ In Morris v. Hitchcock, ${ }^{254}$ the Court explained the effect of opening certain parts of the Chickasaw Reservation to non-Indian settlement:

[It] does not deprive these Indians of the power to enact laws with regard to licenses or taxes, nor exempt purchasers of town or city lots from the operation of such legislation.

Purchasers of lots do so with notice of existing Indian treaties . . . . Such lands are sold under the assumption that the purchasers will comply with the local laws. ${ }^{255}$

The Morris Court upheld the forfeiture of non-Indians' horses and cattle as a result of their failure to pay a permit tax. ${ }^{256}$ Buster $v$. Wright, ${ }^{257}$ an opinion of the Eighth Circuit, in which South Dakota is located, involved a similar issue. There, the question was whether the Creek Nation could enforce its business tax on non-Indian, on-reservation landowners by shutting down the businesses of those who refused to pay. The Eighth Circuit held that such enforcement was proper and constitutional:

[T] he jurisdiction to govern the inhabitants of a country is not conditioned or limited by the title to the land which they occupy in it, or by the existence of municipalities therein endowed with power to collect taxes for city purposes, and to enact and enforce municipal ordinances. ... The theory that the consent of a government to the incorporation and existence of cities upon its territory or to the conveyance of the title to lots or lands within it to private individuals exempts the inhabitants of such cities and the owners or occupants of such lots from the exercise of all its governmental powers . . . is too unique and anomalous to invoke assent. ${ }^{258}$

Remarkably, the Eighth Circuit enunciated this unequivocal holding of tribal jurisdiction over non-Indian patentees within the Creek Reserva-

253. Morris v. Hitchcock, 194 U.S. 384 (1904); Buster v. Wright, 135 F. 947 (8th Cir. 1905).

254. 194 U.S. 384.

255. Id. at 392 (internal quotation mark omitted).

256. Id. at 393.

257. 135 F. 947.

258. $135 \mathrm{~F}$. at $951-52$. 
tion despite the fact that an agreement between the federal government and the Creek Nation provided that the Nation's governmental powers would cease as of March 4, 1906, absent contrary legislation. ${ }^{259}$

Thus, under the governing federal law in South Dakota, non-Indian settlers were on notice, at least as of 1905 , that even if a tribe was slated to have its recognized powers of self-government nullified under federal law, tribal jurisdiction over non-Indians on that reservation would exist until that nullification occurred. This means that non-Indian settlers, after Buster was decided in March 1905, were on notice that they may well be subject to tribal jurisdiction until the reservation they chose to live on was affirmatively disestablished or diminished. In other words, even assuming that non-Indians moved onto reservations with the expectation that the tribes and reservations would eventually disappear, they should have understood the likelihood that they would be subject to tribal jurisdiction in the interim and that that legal framework would continue indefinitely if the project of allotment and assimilation failed. ${ }^{260}$ While other allotment-era cases concerning what constituted Indian country may have caused some uncertainty about how the rules would be applied in any given case, ${ }^{261}$ the strong holdings as to tribal jurisdiction over non-Indians in Morris and Buster would nonetheless have given settlers notice of the fair possibility of some exertion of tribal jurisdiction. ${ }^{262}$

\section{Unclean Hands}

In addition to Habermas's definition of justice and historical law on tribal jurisdiction and on-reservation jurisdictional frameworks, another potentially useful way to elucidate the notion of justifiable expectations is to examine the equitable defense of unclean hands. This is a broadly ap-

259. Id. at 953 .

260. Even if settlers had relied on the information predicting the disappearance of the Cheyenne River Sioux Reservation, see, e.g., Indian Lands Are Disappearing from the Public Domain, supra note 192, such information could not have been reasonably interpreted as giving rise to an expectancy as to lack of tribal jurisdiction.

261. See, e.g., Ash Sheep Co. v. United States, 252 U.S. 159 (1920) (holding that unsold surplus lands within an Indian reservation would be held by the federal government for the benefit of the tribe until sold to non-Indians); Bates v. Clark, 95 U.S. 204 (1877) (addressing the question of what constitutes Indian country for purposes of federal laws prohibiting introduction of liquor into Indian country); see also Solem v. Bartlett, 465 U.S. 463, 468 (1984) (discussing Bates and Ash Sheep); COHEN's HANDBOOK, supra note 4, § 3.04. Like Morris and Buster, Ash Sheep arguably gave non-Indian settlers notice as to the possibility of the continued viability of the reservation boundaries despite a reservation's having been opened, see Ash Sheep, 252 U.S. at 166, although the holdings of the two earlier cases contain much more definitive language as to this issue.

262. Allotment-era non-Indian purchasers are properly understood to be charged with notice of these cases as a legal matter under the general maxim that "ignorance of the law is no excuse." See, e.g., United States v. Int’l Minerals \& Chem. Corp., 402 U.S. 558, 562-63 (1971). 
plicable affirmative defense ${ }^{263}$ that a civil defendant can raise against a plaintiff's cause of action when the plaintiff has "engaged in conduct that is in bad faith or violates other equitable standards," 264 and the defendant has been harmed by the plaintiff's inequitable conduct. ${ }^{265}$ Although equitable defenses such as unclean hands were historically only applicable to cases in which equitable relief was sought, there is an emerging trend toward allowing use of unclean hands to defend against an action at law. ${ }^{266}$

Despite this trend, however, the defense of unclean hands would not normally have any place in determining subject matter jurisdiction for a tribal court or any other court. This is because the question of the existence of subject matter jurisdiction is a metaquestion about the power of the court to hear the case, and this question is conceptually separate from the specific facts surrounding an individual claim for relief and the viability of any defenses to that claim based on the actions of the parties. ${ }^{267}$ Moreover, this Article's focus has been on historical non-Indian purchasers of reservation lands, not on current litigants, whose actions would ordinarily be at issue in adjudication of an unclean hands defense. Nonetheless, the doctrine can provide useful insights here because, as discussed below, the Court's invocation of non-Indians' justifiable expectations is properly understood as a reliance on equitable concerns to justify nonenforcement of a congressional directive. Because of this reliance, it is appropriate to

263. See, e.g., 7-61 THOMPSON ON REAL PROPERTY, supra note 44, $\S 61.07$ (b)(2)(vii) (discussing the applicability of the defense in the context of real covenants law); 25 WILLISTON ON CONTRACTS $\S 67: 18$ (4th ed. 2012) (discussing the doctrine as applied to those seeking specific performance of contracts).

264. Richard A. Cirillo, Commercial Contracts: Strategies for Drafting AND NeGotiatiNG $\S 11.04[B]$, p. 11-35 (Morton Moskin ed., 2012).

265. See, e.g., 7-61 ThOMPSON ON REAL PROPERTY, supra note 44, § 61.07(b)(2)(vii). This second requirement is not enforced in all courts. See, e.g., id.

266. See, e.g., T. Leigh Anenson, Limiting Legal Remedies: An Analysis of Unclean Hands, 99 KY. L.J. 63, 65, 73-74, 99, 101, 104, 107 (2010); see also 1 AM. JUR. 2D ACTIONS § 6 (2012) ("While in some jurisdictions the distinction between actions at law and suits in equity has been retained, in most states equitable remedies are enforced by the ordinary civil action."); 7 WiTKIN, CAL. Proc. JUDGMENT $\S 412$, p. 1052 (5th ed. 2008) (stating that "[b]efore the adoption of the codes, equitable defenses could not even be pleaded in actions at law" in California and that "[u]nder the code system, because they may be freely pleaded, these defenses should be subject to the rules of res judicata"); Thomas O. Main, Traditional Equity and Contemporary Procedure, 78 WASH. L. REV. 429, 431 (2003) (discussing the unification of the systems of law and equity generally throughout the United States).

267. See, e.g., 5B FED. PraC. \& Proc. CIV. $\$ 1350$ (3d ed. 2012) (noting that "an objection to subject matter jurisdiction goes to the power of the court to hear and decide the case"); Grant Christensen, Creating Bright-line Rules for Tribal Court Jurisdiction over Non-Indians: The Case of Trespass to Real Property, 35 AM. INDIAN L. REV. 527, 542-43 (2011) (explaining that Supreme Court cases about tribal court jurisdiction concern such courts' subject matter jurisdiction). 
consider whether equitable defenses such as unclean hands have any role to play in the analysis.

Taking the example of a tribal civil jurisdiction case, federal statutory law, specifically the Indian Country Statute, supports application of tribal civil jurisdiction over conflicts occurring within an Indian reservation, regardless of land ownership or party status as Indian or non-Indian. ${ }^{268}$ Despite this seemingly clear directive, the Supreme Court has developed a complicated common law test for tribal civil jurisdiction over nonmembers under which such jurisdiction is the exception rather than the rule. ${ }^{269}$ Even more troublingly, it tends to apply the test very narrowly and rarely holds that a tribe has civil jurisdiction over nonmembers. ${ }^{270}$ Part of the Court's rationale for applying the test and construing it narrowly is its concern for the justifiable expectations of allotment-era non-Indian purchasers. ${ }^{271}$ Thus, the Supreme Court employs these purported justifiable expectations as a sort of equitable defense to the mandate of the Indian Country Statute. But, given the historical information about justifiable expectations delineated above, which shows settler complicity in abrogation of tribal rights in some cases and notice of the federal government's dishonorable dealings with tribes in many others, current litigants should not be entitled to invoke the justifiable expectations of their predecessors in interest to avoid the directives of the Indian Country Statute. The fact that many such predecessors likely had unclean hands should vitiate current litigants' ability to invoke an equitable defense on their predecessors' behalf under the maxim that "he who seeks equity must come with clean hands.", ${ }^{272}$ Buying land with notice that it had unfairly been taken from tribes or after having personally advocated for such a taking is surely "inequitable conduct" that is "directly related to the contractual relationship between" the federal government and the initial non-Indian purchaser so as to warrant invocation of the unclean hands doctrine. ${ }^{273}$

268. 18 U.S.C. $§ 1151$ (2012); see also Fletcher, supra note 5, at 822-23 (discussing the Indian Country Statute, 18 U.S.C. § 1151); Valencia-Weber, supra note 5, at 473 (same).

269. See generally Montana v. United States, 450 U.S. 544 (1981).

270. See, e.g., Tweedy, supra note 5, at 674-83.

271. See supra Part III.

272. CIRILLO, supra note 264, at 11-35.

273. Id. Another problem with the Court's analysis of justifiable expectations in this context is that it seems to focus exclusively on non-Indian expectations, taking no account whatsoever of tribal or individual Indians' expectations. See, e.g., Tweedy, supra note 5, at $707 \&$ n.274. A rigorous examination of justifiable expectations would need to examine whether parties on both sides of a dispute had such expectations. In the case of the Cheyenne River Sioux Tribe, it seems clear that the Tribe had justifiable expectations that its reservation would not be opened to settlement, at least not to 


\section{State Succession}

Another promising doctrine-based approach to justifiable expectations is the use of the international law of state succession by analogy. "State succession arises when there is a definitive replacement of one state by another in respect of sovereignty over a given territory in conformity with international law." ${ }^{274}$ As a preliminary note, the federal government's recognition of greater tribal powers of self-government such as occurred after allotment had ended would not literally qualify as state succession from the United States to the tribal government at issue because tribes' powers presumably remained very limited with respect to international affairs and because the federal government still retained significant power on reservations. ${ }^{275}$ Nonetheless, the situation of a tribe whose governmental powers were initially limited under the laws of the colonizing nation but then received expanded recognition under those laws due to a change in the colonizer's policies is sufficiently similar to state succession (under which the federal power would literally be replaced by tribal power) to warrant comparison. ${ }^{276}$ Although state succession has been described as "an area of great uncertainty and controversy," 277 it is generally understood that " $[t]$ he new sovereign receives the same sort of sovereignty as the transferor has had, and this involves normal powers of legislation and jurisdiction deriving from sovereign equality and the reserved domain of domestic jurisdiction." 278 An allotment-era treatise similarly suggests that the successor state is normally

the degree that it was. See, e.g., supra notes 166-69 and accompanying text (describing the Cheyenne River Sioux Tribe's reaction to the proposed opening).

274. IAN Brownlie, Principles of Public InTERnATIONAL LAW 649 (7th ed. 2008).

275. See JAMES CRAWFORD, THE CREATION OF STATES IN INTERNATIONAL LAW 63, 67 (2d ed. 2006); see also 1 L. OPPENHEIM, INTERNATIONAL LAW: A TREATISE 132-33, 141-42 (1912 ed.) (suggesting that when one nation is in a subordinate relationship with another nation, the degree of independence of the former with respect to international affairs is determinative as to whether the former will be recognized in the international family of nations). Courts have held that tribes' powers with respect to international affairs have been extremely curtailed as a consequence of the relationship between tribes and the United States. See, e.g., Cherokee Nation v. Georgia, 30 U.S. (5 Pet.) 1, 17-18 (1831) ("They [the Cherokee Nation] and their country are considered by foreign nations, as well as by ourselves, as being so completely under the sovereignty and dominion of the United States, that any attempt to acquire their lands, or to form a political connexion with them, would be considered by all as an invasion of our territory, and an act of hostility.").

276. See BROWNLIE, supra note 274, at 652 (discussing state succession in the context of decolonization).

277. Id. at 650 .

278. Id. at 652 . 
entitled to exercise jurisdiction over all those found within its boundaries, including foreigners. ${ }^{279}$

The international law of state succession thus reinforces the idea that non-Indian purchasers during the allotment era did not have justifiable expectations as to lack of tribal jurisdiction. When the government of a nation or of a portion of a nation changes hands, as occurs with state succession, the new government has all of the ordinary powers of jurisdiction and legislation, and the citizens of the former government have no vested right to insist otherwise (absent a treaty providing such a right). The change in federal policy from one that oppressed tribes and sought to squelch their culture to one that attempted greater respect and allowed for greater self-rule is sufficiently similar to state succession through decolonization for the same rules regarding jurisdiction to apply. Moreover, protections currently exist under federal law for non-Indians and others who are subject to tribal jurisdiction, and these protections are similar to those that might be found in a treaty governing state succession. ${ }^{280}$ Thus, there is no practical reason not to apply the analogy of state succession. The fact that international law recognizes the jurisdiction of new states over the citizens of the previous states as a matter of course suggests that there is nothing anomalous about recognizing tribal jurisdiction in the similar framework of partial decolonization and therefore that historical non-Indian purchasers could not have had justifiable expectations of immunity from tribal jurisdiction.

\section{Notice Under Real Covenants Law}

As described earlier in this Article, the Supreme Court and individual Justices sometimes equate tribal jurisdiction over non-Indians on non-Indian-owned fee lands within a reservation to a real covenant or equitable servitude and then posit that the servitude or covenant is invalid because the original non-Indian purchaser was not on notice of the possibility of tribal jurisdiction. The conflation of the law of servitudes and tribal jurisdiction is problematic for a variety of reasons, ${ }^{281}$ perhaps most notably because, as the Buster court emphasized, other sovereigns' governance rights are not tied to land ownership. ${ }^{282}$ Nonetheless, the re-

279. 1 OPPENHEIM, supra note 275 , at 154 (describing the situation of Turkey, where foreigners were "still under the exclusive jurisdiction of their consuls" as "an anomaly" that stemmed partly from treaties and partly from custom).

280. See, e.g., 25 U.S.C. $\$ 1302$ (2012).

281. Tweedy, supra note 17 , at 164-65.

282. Buster v. Wright, 135 F. 947, 951-52 (8th Cir. 1905). 
quirement of notice in real covenants and equitable servitudes law can help us assess non-Indian purchasers' expectations.

For a real covenant or equitable servitude to be valid, the party to be bound must have had notice of it at the time of purchase. ${ }^{283}$ As mentioned above, non-Indian purchasers had notice of federal laws supporting tribal self-government as of 1934. Purchasers also had notice of laws specifically defining non-Indian-owned land within a reservation as Indian country - making the land presumptively subject to tribal jurisdiction - as of 1948 (and continuing into the present day). That leaves the question of what notice allotment-era buyers might have had. While Buster and Morris provided notice that would appear to be more than sufficient, the newspaper articles analyzed above are another potential source of notice. The information contained in them was likely available to the general public through newspapers, other widely available publications, and word of mouth. Indeed, given the breadth of newspaper coverage about tribes and tribal issues (albeit usually from a decidedly non-Indian perspective), it can only be assumed that tribal issues were very much a topic of ordinary conversation among non-Indians during the allotment era. ${ }^{284}$

Because the vast majority of news articles discussed above do not relate in any sense to tribal jurisdiction, it is unlikely that reading the newspapers would have put non-Indians on actual, explicit, and direct notice of the possibility of tribal jurisdiction, ${ }^{285}$ although the articles that describe settlers' advocacy to open specific reservations for non-Indian settlement arguably rise to this level. Constructive notice, which tends to be tied to the researching of a chain of title for a given piece of property, also seems largely inapposite here. ${ }^{286}$ That leaves inquiry notice. Inquiry notice is defined as "notice from the subsequent purchaser's actual knowledge or constructive notice of facts which would have caused a

283. See, e.g., John G. Sprankling, Understanding Property LaW § 33.04[B][7] (2d ed. 2008) (explaining that bona fide purchasers must have notice of real covenants pursuant to recording statutes); id. $\S 34.04[\mathrm{~B}][5]$ (discussing the notice requirement for equitable servitudes); 7-61 THOMPSON ON REAL PROPERTY, supra note 44, § 61.04(f) (describing notice as a general requirement but noting that it is not universal in the case of real covenants).

284. See, e.g., Indians Cast First Vote at an Election, Ashton Chron., June 17, 1910, at 2 (describing the Standing Rock Sioux citizens' actions in voting for local, state, and federal candidates); Big Social Event in Indian Circles, DAILy ARGus LEADER, Apr. 18, 1908, at 2 (describing an important wedding on the Crow Creek Reservation); The Bear Dance, supra note 229 (contrasting the hardworking Cheyenne River Sioux Indians with the Indians on the Ute Reservation and arguing for assimilationist training on that basis).

285. But see Clash in Authority, supra note 149; In Conflict of Authority, supra note 149.

286. See 11-92 THOMPSON ON REAL PROPERTY, supra note 44, § 92.09(c) (tying constructive notice to those facts that could have been ascertained through a reasonable inspection of the property and through a reasonable title search). 
reasonable person to make further inquiries; a subsequent purchaser is deemed to have notice of all facts that such inquiries would have uncovered." ${ }^{287}$ While some articles cited are not sufficient to put a reader on inquiry notice of the possibility of tribal jurisdiction, those that describe tribal opposition to specific proposed land cessions or reservation openings would have put potential purchasers on notice of the possibility that the land being sold had been unjustly taken from tribes, especially given that the land at issue had generally been guaranteed to the tribes through solemn treaties and that several articles conveyed this treaty-protected status. Other articles, such as those merely alluding to the treaty-protected status of tribal property, may have also provided inquiry notice.

Non-Indians who were privy to information regarding tribal opposition, but who chose nonetheless to buy the land from the federal government, would have been on inquiry notice that the tribal owner might have some type of continuing claim to it in equity if not under then-current law. In some cases, the notice provided by the article may have been sufficient to demonstrate the possibility of such a continuing claim in and of itself. ${ }^{288}$ With more ambiguous articles, ${ }^{289}$ some type of reasonable investigation, such as seeking information from the tribal council, the Indian agent, or the Department of Interior would likely have confirmed that tribal lands had been taken without tribal consent. The obvious difficulty for the tribe would have been enforcing that equitable claim, but even that difficulty was not necessarily insurmountable under then-existing law.

Although non-Indian buyers may well have known that the Supreme Court had declared the federal government to have the power to unilaterally deprive tribes of property rights, ${ }^{290}$ this holding would not be determinative of whether the tribe would ever have any power over the land whatsoever. First, as discussed above, the Lone Wolf Court did not make any pretense of dealing justly with the plaintiffs in that case; rather, the Court merely held that their claim could not be heard against the federal government in federal court. Whether their claims had continuing viability in a moral sense or might be remedied through other means, such as through a legislative enactment, was not addressed and such possibilities were certainly not foreclosed. Instead, Lone Wolf merely held that in disputes between a tribe and Congress, the tribe is basically at the mercy

287. Id.

288. See, e.g., CHI. DAILY TRIB., June 6, 1875, supra note 96.

289. See, e.g., Opening of Schnasse County, supra note 182.

290. Lone Wolf v. Hitchcock, 187 U.S. 553 (1903); Lone Wolf Defeated., ANADARKO DAILY DEMOCRAT, Jan. 6, 1903, at 1 . 
of Congress. ${ }^{291}$ At the same time, however, the Court affirmed the continued validity of precedents supporting tribal property and other rights when the dispute was between a tribe and individuals or states. ${ }^{292}$ Thus, non-Indian purchasers who knew that tribal property rights were being violated also should have known that, although the tribe may not have been able to enforce its property rights against the federal government under the law as it existed at that time, tribes nonetheless had the option of trying to convince the federal government to change its policies and that the tribe's remaining rights were enforceable against incursions by states or individuals. Indeed, allotment-era news stories reflect the federal government's willingness, in some cases, to protect tribal property rights against abuses by others and further note the possibility of changes in the federal allotment policy that would be favorable to tribes. ${ }^{293}$ The news articles describing tribal opposition to the taking of tribal property therefore put potential non-Indian purchasers on inquiry notice of the fact that tribes may have continuing equitable claims to such property, and Lone Wolf did not foreclose all avenues of relief for such claims.

Finally, tribal regulatory and adjudicatory jurisdiction does not deprive a land owner of title, nor does it necessarily imply any special limitations on land use. If it is a burden on property ownership at all, it is a modest one and in no way out of proportion to the grave injustices inflicted on tribes during the allotment era and their resulting equitable claims to some continued interest in their alienated reservation lands.

It is important to recognize that importing the notion of inquiry notice into the allotment context is not a seamless process. In the allotment context, it is not as though the non-Indian purchasers, by conducting a reasonable investigation, could have turned up evidence of an agreement under which the newly purchased property would be continually subject to tribal jurisdiction. Instead, the most that could be expected is that lack of tribal assent and other injustices, such as governmental coercion, would be revealed or confirmed through such an investigation. The imperfect fit between the notion of inquiry notice and continuing tribal jurisdiction on opened reservations is due to the fact that tribal jurisdiction is a creature of tribal and federal law and not generally an appropriate subject for real covenants and equitable servitudes. The reach of a sovereign's police power is properly thought of as a public question, not as a subject for private transactions among neighbors relating to property use. Addition-

291. Lone Wolf, 187 U.S. at 565-66.

292. Id. at 564-65; see generally United States v. Winans, 198 U.S. 371 (1905).

293. Burke Is Reticent About Findings, supra note 200; Save Lands for Indians, supra note 200; The Crow Creek Reservation, supra note 200; Will Try to Save Land for Indians, supra note 200. 
ally, unlike real covenants and equitable servitudes, which generally must touch and concern the land to be valid, ${ }^{294}$ tribal jurisdiction does not intrinsically have anything to do with land use. Nonetheless, given judicial analogies between tribal jurisdiction and real covenants and equitable servitudes, it is useful to look through the lens of inquiry notice and see that non-Indian purchasers during the allotment era in many cases had "notice of facts that would have aroused the suspicions of a prudent purchaser and caused that purchaser to make further investigations." 295 In this case, those suspicions would not have concerned restrictions based on real covenants or equitable servitudes but would have instead concerned whether the lands being sold were taken from tribes unjustly and whether the tribes might therefore have some continuing interest in the lands. Given the modest character of the incursion of tribal jurisdiction ${ }^{296}$ and the notice to non-Indians of a possible continuing tribal interest that was present in many cases, the recognition of tribal jurisdiction over open areas and other non-Indian-owned properties on reservations is a fair compromise. Applying the concept of inquiry notice also indicates that the test for diminishment should be rethought, and some existing decisions should be reevaluated because non-Indians' expectations may not have been justifiable given the widely available evidence of injustice in many cases and the current laws supporting tribal jurisdiction.

\section{CONCLUSION}

The newspaper articles discussed above demonstrate that many non-Indians would have had information to the effect that individual tribes objected to the opening of their reservations and further that many tribes had treaty-protected property rights to the reservations that were opened. Indeed, in some cases, settlers themselves advocated for the taking of Indian lands. Moreover, a philosophical definition of justice rooted in the work of Jürgen Habermas reveals the injustice of these historical takings of tribal lands.

This information suggests that non-Indians who purchased lands on reservations in many cases did not have justifiable expectations that they would take their land free and clear of any continuing tribal interest. This is because knowledge of such injustice conflicts with the ordinary meaning of justifiable expectations, and knowledge of an unjust taking should be interpreted to constitute notice that tribes may have some continuing

294. SPRANKLING, supra note 283, §§ 33.04[B][4], 34.04[B][4]; 7-61 THOMPSON ON REAL PROPERTY, supra note $44, \S 61.04(\mathrm{~d})$.

295. 11-92 THOMPSON ON REAL PROPERTY, supra note 44, § 92.09(c)(3).

296. See, e.g., Tweedy, supra note 5, at $685 \mathrm{n} .163$ (discussing tribal court jurisprudence). 
interest in the lands. Finally, (1) the relevant case law and statutory law of the time that had some bearing on on-reservation jurisdiction did not support the view that tribal jurisdiction was foreclosed, (2) the law of state succession raises the likelihood of tribal jurisdiction, and (3) the doctrine of unclean hands suggests that the successors of allotment-era non-Indian purchasers should not be able to benefit from the original purchasers' presumed expectations.

In conclusion, it is simply not accurate for courts to assume that non-Indian purchasers of surplus lands during the allotment era had justifiable expectations that they would not be subject to tribal jurisdiction. This rationale for denying tribal jurisdiction over non-Indians, and for holding reservations to have been diminished or disestablished, should be abandoned. Instead, courts should enforce presumptions in favor of tribal jurisdiction and stable reservation boundaries, which are more in accord with both current statutory law and longstanding tribal expectations that are themselves based on solemn treaties and other intergovernmental agreements as well as on the federal government's trust duties toward tribes. In other words, the ghosts of allotment-era settlers should finally be laid to rest. 